\title{
The Impact of State Aid for Restructuring on the Allocation of Resources*
}

\author{
Helena Schweiger ${ }^{\dagger}$ \\ EBRD
}

December 27, 2006

\begin{abstract}
Recent empirical work has shown that the success of an economy depends largely on how successful it is in allocating inputs and outputs across businesses efficiently with minimum disruption and frictions. Market institutions that impact this allocation potentially account for productivity differences across countries. Existing studies use quite broad measures of institutions, mostly at the country level and/or using survey data with questionable representativeness. This paper is the first to use census micro level data on a market institution with a potentially very distortive effect, namely state aid for the rescue and restructuring of firms in difficulty. Such aid can postpone the exit of unprofitable firms and thus shift the burden of structural adjustment onto more efficient firms who are managing without it. We investigate the impact of this aid on static and dynamic efficiency of Slovenian manufacturing
\end{abstract}

\footnotetext{
*Updates of this paper can be downloaded at http://www.helenasch.net/.

${ }^{\dagger}$ Email: helena.schweiger@gmail.com. I am extremely grateful to John Haltiwanger, John Shea and Jeff Smith for encouragement and many valuable comments. I also wish to thank Marcela Eslava, Peter Murrell, Borağan Aruoba, Allan Drazen, Jonah Gelbach, Gunjan Sharma, Isabel Rodriguez-Tejedo and workshop participants at the University of Maryland, Central European University, University of Reading and European Bank for Reconstruction and Development for helpful comments and Marko Simoneti, Ana Murn, and Igor Naglič for helpful discussions. Finally, I wish to thank the following people and agencies for the help with obtaining the data and relevant information: Aljoša Valentinčič from PASEF, Lea JagodičLekočevič and Darko Sajko from the Commission for State Aid Control at the Ministry of Finance of the Republic of Slovenia, Bogdan Topič, Matjaž Lukač, Milan Vodopivec, Agency of the Republic of Slovenia for Public Legal Records and Related Services (AJPES), and Statistical Office of the Republic of Slovenia (SORS). All errors are my own. The views expressed in this paper are my own and do not necessarily represent those of the EBRD.
} 
by combining the aid data with firm-level accounting data. Evaluating the impact of state aid on static and dynamic efficiency of an economy is difficult due to the lack of a counterfactual and because of selection bias. The latter arises because firms that receive aid may differ from firms that do not receive aid along other dimensions. We use treatment effects estimators that assume selection on observables (linear regression models) and estimators that explicitly allow for selection on unobservables (instrumental variables and selection models). Our identification strategy in the latter models involves using variables that affect the chances of getting aid before 2002, but not after. The empirical analysis reveals that state aid hindered the efficient static allocation of resources, as measured by the Olley and Pakes [1996]-inspired micro covariance measure. None of the firms that received aid exited, aid had a positive impact on the growth rate of market shares, but did not have a significant impact on the growth of TFP. These results suggest that aid was distortive.

JEL Classification: C21, L2, L53, O47, P31.

Keywords: Allocative efficiency, State aid, Treatment effects, Transition.

\section{Introduction}

Aggregate productivity growth has been the subject of numerous studies, and our understanding of it as well as its measurement has improved since Solow [1957]. We now know that the representative firm paradigm, on which the aggregate production function approach is based, does not hold in the real world; on the contrary, there is substantial heterogeneity across businesses. Longitudinal micro business databases are becoming more widely available, allowing one to study the restructuring of economies due to a continuous process of entry and exit of businesses, and expansion and contraction of incumbents.

Recent empirical work has shown that the success of an economy depends largely on how successful it is in allocating inputs and outputs across businesses efficiently with minimum disruption and frictions (see, e.g., Eslava et al. [2004]). The process of allocation consists of two complementary components, cross-sectional (static) allocation and longitudinal (dynamic) allocation of inputs and outputs from less productive to more productive businesses. Olley and Pakes [1996] investigate the first component, whether more productive businesses have a higher market share. The importance of the second component is explored by, among others, Foster et al. [2001]. They find that most productivity growth (using a five-year window) is explained by growth within firms, but that the net contribution of entry and exit is far from negligible. 
Cross-country studies find that there are substantial differences among countries both in the contribution of continuing, entering and exiting firms to aggregate productivity growth as well as in their cross-sectional allocative efficiency. Possible explanations for this heterogeneity lie in different market institutions and market structures. Caballero and Hammour [2000] argue that the function of institutions is twofold, one of efficiency and one of redistribution, and both are important for macroeconomic outcomes. A poor institutional environment results in technological "sclerosis" since it "permits low-productivity units to survive longer than they would in an efficient equilibrium" (Caballero and Hammour [2000], p. 20) and thereby causes stagnation in the process of creative destruction. Escribano and Guasch [2004] and Haltiwanger and Schweiger [2005] find that an adverse business climate has a negative impact on static allocative efficiency. Eslava et al. [2004] find that after market reforms in Colombia, the net contribution of entry and exit to aggregate productivity rose slightly and that surviving entrants exhibited more rapid productivity growth than incumbents. Olley and Pakes [1996] reach a similar conclusion for static allocative efficiency in the telecommunications equipment industry after a deregulation. Based on the evidence from a number of developing countries, Tybout [2000] suggests that policies matter: "market share turnover rates are much higher in Korea and Taiwan than in Latin America, where labor markets are relatively regulated" (p. 27).

A problem with the above studies is that they use quite broad measures of institutions, mostly at the country level, and/or survey data with questionable representativeness of the entire economy. ${ }^{1}$ This paper is the first to use census micro level data on a market institution with a potentially very distortive effect, namely state aid for the rescue and restructuring of firms in difficulty. ${ }^{2}$ Such aid can postpone the exit of unprofitable firms and thus shift the burden of structural adjustment onto more efficient firms who are managing without it. This problem is relevant not only in transition and developing economies, but also in developed economies. State aid provides soft budget constraints to the firms receiving it, and soft budget constraints have an influence on the life-cycle of firms and thus market selection, which in turn affects aggregate productivity growth. ${ }^{3}$ A study by London Economics [2004] is the only existing work to evaluate the impact of rescue and restructuring aid on international competitiveness, but they focus only on a few sectors and case studies.

We investigate the impact of aid for the rescue and restructuring of firms in difficulty

\footnotetext{
${ }^{1}$ Surveys such as the World Bank's Productivity and Investment Climate Survey tend to focus on medium and large businesses, and hence their samples are not necessarily representative of the entire economy.

${ }^{2}$ In this paper, "state aid" and "aid" refer to the state aid for the rescue and restructuring of firms in difficulty, unless explicitly stated otherwise.

${ }^{3}$ See Kornai et al. [2003] for a definition and survey of the soft budget constraints literature.
} 
on static and dynamic efficiency ${ }^{4}$ of Slovenian manufacturing in the period from 1998 to 2003 by combining firm-level data on state aid with firm-level accounting data and information on aid legislation. Slovenia is a transition economy, but major changes in its economy happened prior to 1998, and it is comparable to other old EU member countries in terms of state aid per capita and percentage of sectoral aid in GDP, which includes restructuring and rescue aid. ${ }^{5}$ The majority of non-agricultural state aid has been oriented towards manufacturing in almost all members of the EU, and policy makers in many countries have paid special attention to manufacturing, either because they view it as "the leading edge of modernization and skilled job creation, as well as a fundamental source of various positive spillovers" (Tybout [2000], p.11) or because a lot of restructuring was going on in manufacturing in the 1990s.

Evaluating the impact of aid on static and dynamic efficiency is difficult due to the lack of a counterfactual and the need to handle selection bias. The latter arises from the fact that firms that receive aid usually differ from firms that do not receive aid along other dimensions. We use treatment effects estimators that assume selection on observables and estimators that explicitly allow for selection on unobservables. Our identification strategy in the latter models involves firm-level variables that affect the likelihood of receiving aid prior to 2002, but not after 2002, when Slovenia sharply scaled back its aid in order to comply with EU regulations. None of the firms that received aid ceased to exist during this period and, overall, exit rates were low compared to those in the OECD countries, so most of the "action" happened among the continuing firms and the allocation of resources among them. The empirical analysis reveals that state aid for the rescue and restructuring of firms in difficulty hindered the efficient allocation of resources, and that it had a positive impact on the growth rate of market shares of weak firms. This indicates that aid had a distortive effect.

The outline of the paper is as follows. In Section 2, we review related literature on static and dynamic efficiency. We describe the background and data sources in Section 3. In Section 4, estimation methods are discussed and Section 5 presents the results. Section 6 concludes.

\footnotetext{
${ }^{4}$ From the social viewpoint, such aid might have some positive effects, such as keeping people employed, but we are primarily interested in its impact on allocative efficiency.

${ }^{5}$ This can be seen from the data on state aid in Commission of the EC [2004], presented in Table A.1.
} 


\section{Allocative Efficiency}

Aid can postpone the exit of unprofitable firms and thus shift the burden of structural adjustment onto more efficient firms who are managing without it. Hence, aid can have an impact not only on the exit decision of firms, but also on the allocation of inputs and outputs across firms. Aggregate productivity growth depends on both, as we explain in Sections 2.1 and 2.2 .

\subsection{Static Allocative Efficiency}

Aggregate productivity and its growth depend not only on how productive businesses are on average, but also on whether more productive businesses have a higher market share. Olley and Pakes [1996] show this formally by decomposing aggregate productivity $P$ in an industry $j$ at time $t$ as follows:

$$
\begin{aligned}
P_{t, j} & =\bar{p}_{t, j}+\sum_{i=1}^{H_{t, j}} \Delta s_{i t, j} \Delta p_{i t, j} \\
\Delta s_{i t, j} & =s_{i t, j}-\bar{s}_{t, j} \quad \Delta p_{i t, j}=p_{i t, j}-\bar{p}_{t, j}
\end{aligned}
$$

where $i$ denotes firm, $t$ denotes time, $j$ denotes 2-digit industry, bar denotes unweighted average, $H$ represents the number of firms, $s$ is firm $i$ 's domestic market share in industry $j$ and $p$ is a measure of productivity.

The first term in (1) is unweighted average productivity in industry $j$ at time $t$ and the second term is a covariance term, which measures cross-sectional allocative efficiency. Ideally, this covariance would be positive, which happens when firms with higher (lower) productivity than average have higher (lower) than average market shares. Besides providing an intuitive and compact measure of allocative efficiency, another advantage of the covariance is that it is more comparable across sectors than average productivity itself, since the first moment differences across sectors are differenced out. It is a cross-sectional measure, but it makes sense to compare its values over time: a higher covariance in year $t$ than in year $t-1$ implies that the economy has improved its allocative efficiency.

Based on equation (1), there are two sources of aggregate productivity growth: im- 
provements in productivity of the average firm and improvements in allocative efficiency:

$$
P_{t, j}-P_{t-1, j}=\left(\bar{p}_{t, j}-\bar{p}_{t-1, j}\right)+\left(\sum_{i=1}^{H_{t, j}} \Delta s_{i t, j} \Delta p_{i t, j}-\sum_{i=1}^{H_{t-1, j}} \Delta s_{i t-1, j} \Delta p_{i t-1, j}\right) .
$$

Olley and Pakes [1996] find that in the US telecommunications equipment industry, the source of aggregate productivity growth was the reallocation of output from less productive to more productive plants. Following the deregulation of the industry, the allocation of output improved significantly.

A burgeoning literature of cross-country studies, such as Bartelsman et al. [2005] using a World Bank dataset on firm demographics and productivity, ${ }^{6}$ find that there is substantial heterogeneity in static allocative efficiency among countries. Escribano and Guasch [2004] and Haltiwanger and Schweiger [2005] use firm-level data from the World Bank's Productivity and the Investment Climate Survey and come to a similar conclusion.

We use TFP as a measure of productivity. Labor-productivity-based covariance only looks at whether workers and output are allocated in less productive or more productive firms, and this captures only part of allocative efficiency, since workers are not the only input used in production. For the economy to achieve a higher productivity, other inputs such as capital need to be allocated to more productive firms as well. If a firm lays off workers who subsequently find work in more productive firms, but keeps the machinery and equipment these workers used laying idle, this will have a positive impact on laborproductivity-based covariance, but not necessarily on TFP-based covariance. Due to this fact and the problems with the measure of labor mentioned in Appendix B, where a more detailed description of productivity measurement is available, our preferred measure of productivity is TFP.

We define a firm-level measure of allocative efficiency, called micro covariance, as a cross product between the percentage deviation of the firm's market share from the average market share in industry $j$ and the deviation of the firm's log productivity from the average firm-level log productivity in industry $j$. That is,

$$
\frac{\Delta s_{i t, j}}{\bar{s}_{t, j}} \Delta p_{i t, j}
$$

Escribano and Guasch [2004] define a similar micro covariance measure without di-

\footnotetext{
${ }^{6} \mathrm{~A}$ detailed technical description of the dataset may be found in Bartelsman et al. [2004a]. It contains several firm demographics and productivity indicators and was prepared using firm-level data.
} 
viding by $\bar{s}_{t, j}$. The advantage of the definition in equation (3) is that it is independent of scale, since it is a product of a percentage deviation and a log deviation. The measure of allocative efficiency defined in (3) is interpreted as the contribution of a firm to aggregate allocative efficiency. If the firm has above average productivity and above average market share, then this measure is positive and shows that the firm contributes positively to aggregate allocative efficiency. If a firm has below average productivity, but above average market share, this measure is negative and implies that there are some imperfections in the economy that allow the less productive firm to keep a higher market share than would correspond to its lower than average productivity. Note that this measure is equal to zero in the case of a monopoly as well as perfect competition - the second term in (1) is equal to zero in both of these extreme cases.

Both Escribano and Guasch [2004] and Haltiwanger and Schweiger [2005] examine the empirical relationship between cross-country differences in static allocative efficiency and cross-country differences in business climate. They find that an adverse business climate has an adverse impact on static allocative efficiency. Escribano and Guasch [2004] show that simple non-linear models with interaction terms explain almost 30 percent of the efficiency variation between Guatemala, Honduras and Nicaragua.

One drawback to both of these papers is that they use survey data that over-represents medium and large firms and old firms, as shown in Haltiwanger and Schweiger [2004]. In addition, the data consist only of continuing firms; entry and exit cannot be measured. A second potential drawback is that the business climate indicators are based on the qualitative, subjective responses of firm administrators, and measure the perception of firms about the business climate in the country, not the actual business climate. For certain purposes that is precisely what is desired, but the causal interpretation of the link between the perception of the business climate and firm performance is problematic. On the one hand, firms may be convinced that an adverse business climate is the main culprit for their woes and use it as an excuse not to take steps to improve performance. On the other hand, a firm that is doing well will probably be satisfied with the business climate. Perception of the business climate might also depend on who answers the survey and his or her attitude towards the government. The advantage of our paper is that it uses administrative census firm-level data on state aid and firm characteristics.

\subsection{Dynamic Allocative Efficiency}

Reallocation of output from less productive to more productive firms is facilitated by reallocation of output among continuing firms as well as by entry and exit, as Olley and Pakes 
[1996] note. Griliches and Regev [1995] decompose the growth of aggregate productivity into contributions of continuing, entering and exiting firms: ${ }^{7}$

$$
\begin{aligned}
\Delta P_{t}= & \sum_{i \in C}\left(\frac{s_{i t}+s_{i t-k}}{2}\right)\left(p_{i t}-p_{i t-k}\right) \\
& +\sum_{i \in C}\left(s_{i t}-s_{i t-k}\right)\left[\left(\frac{p_{i t}+p_{i t-k}}{2}\right)-\left(\frac{P_{t}+P_{t-k}}{2}\right)\right] \\
& +\sum_{i \in N} s_{i t}\left[p_{i t}-\left(\frac{P_{t}+P_{t-k}}{2}\right)\right]-\sum_{i \in X} s_{i t-k}\left[p_{i t-k}-\left(\frac{P_{t}+P_{t-k}}{2}\right)\right],
\end{aligned}
$$

where $\Delta$ now represents a change between year $t-k$ and year $t,{ }^{8} p_{i t}$ is the $i$-th firm's productivity level, $s_{i t}$ is the $i$-th firm's share of output, $C, N$, and $X$ are sets of continuing, entering and exiting firms, respectively, and $P_{t}$ is the aggregate productivity level in year $t$. The first term is the within-firm effect, which reflects within-firm productivity growth weighted by the average output share. The second term is the between-firm effect, reflecting the gains in aggregate productivity coming from the expanding market shares of high productivity firms, or from low productivity firms' shrinking shares. The last two terms capture the contribution of entering and exiting firms, respectively.

Using the already mentioned World Bank dataset on firm demographics and productivity, Bartelsman et al. [2004b] find that most productivity growth (using a five-year window) is explained by the within-firm component, but the net contribution of entry and exit is far from negligible - it is generally positive and accounts for between 20 to 50 percent of total productivity growth. Schumpeterian "creative destruction" is thus occuring, as more productive entrants appear to displace less productive exiting businesses.

However, this does not mean that it is not worth looking at countries with a low contribution of entering and/or exiting firms. In that case, the reallocation of output happens predominantly among continuers, and the fact that the contribution of entering and/or exiting firms is low could indicate there are some important frictions in the economy. Indeed, existing studies find that market institutions play an important role. Disney et al. [2003b] find that increased competition boosts productivity and, on the flip side, that keeping poorly performing plants alive removes an important contribution to productivity growth. Similarly, Olley and Pakes [1996] find that deregulation in the telecommunications industry "improved performance by inducing a reallocation of capital to more productive

\footnotetext{
${ }^{7}$ Other versions of this decomposition are shown by Baldwin and Gorecki [1991], Baldwin [1995] and Foster et al. [2001].

${ }^{8}$ Note that in equation (1), $\Delta$ represents a deviation from an unweighted average, and is a cross-sectional difference.
} 
plants" (p. 1292).

We follow standard conventions in the literature to define continuing, entering and exiting firms. We determine continuing firms, entering, exiting, and one-year firms on the basis of the availability of their accounting data, using the following conventions: ${ }^{9}$

$\begin{array}{ll}\text { Firm Type } & \text { Definitions } \\ \text { Continuing firm (CO) } & \text { Exists in } t-1, t \text {, and } t+1 \\ \text { Entering firm (EN) } & \text { Exists in } t \text { and } t+1 \text {, but not in } t-1 \\ \text { Exiting firm (EX) } & \text { Exists in } t-1 \text { and } t \text {, but not in } t+1 \\ \text { One-year firm (OY) } & \text { Exists in } t \text {, but not in } t-1 \text { and } t+1\end{array}$

\subsection{Aid for the Rescue and Restructuring of Firms and Alloca- tive Efficiency}

Theories of market selection (for example, Jovanovic [1982] and Caballero and Hammour [1994]) point out the productivity-survival link as a "crucial driver of productivity growth" (Foster et al. [2003]): more productive firms grow while less productive firms shrink and eventually cease to exist. Aid to firms in difficulty can prolong the life span of firms and thus have an impact on allocative efficiency. It may help low productivity firms obtain higher market shares, stifling the market shares of high productivity firms, and have a negative impact on static allocative efficiency. The measure proposed in Section 2.1 has the advantage of addressing both the market share and productivity channels of impact on aggregate productivity succinctly, and could as such be a good indicator for the impact of aid. Its disadvantages are that it provides no information on which one of the two channels is actually affected by aid and that it provides no information on the impact of aid on exit.

There are a couple of alternative ways of gauging the impact of aid on reallocation: through its impact on exit decisions or through its separate impacts on the growth of market shares and productivity. We define the growth rate of market shares using the Davis et al. [1996] definitions as:

$$
\frac{s_{i t, j}-s_{i t-1, j}}{0.5 *\left(s_{i t, j}+s_{i t-1, j}\right)}
$$

\footnotetext{
${ }^{9}$ Since some firms have missing data for some years, strictly applying the above rule would result in spurious entry and exit. We account for such missing years in our measurement procedure. For example, if firm $\mathrm{A}$ is in the sample in $t-1$ and $t$, as well as in $t+2$, but not in $t+1$, we treat firm $\mathrm{A}$ as a continuing firm in $t$. We rely on firm birth data in combination with the above rule to identify entering firms. We use the online Business Register and the Official Gazzette to determine whether a firm actually exited or ceased to exist as a result of a merger or acquisition, in which case we do not classify it as an exiting firm.
} 
This growth rate measure ranges from -2 to +2 and treats expansion and contraction symmetrically, unlike the conventional growth rate measure. The growth rate of productivity is defined as the difference in log productivity, $p_{i t}-p_{i t-1}$.

We consider all of the above mentioned indicators in this paper. Before proceeding to the estimation methodology and results, we describe the data and the relevant background information, that forms the basis of our estimation strategy.

\section{Data Sources and Institutional Background}

\subsection{Data Sources}

The data for our research come from six major sources: PASEF - The Data Analysis Service of the Faculty of Economics at the University of Ljubljana; CSAC - Commission for State Aid Control at the Ministry of Finance of the Republic of Slovenia; the Statistical Office of the Republic of Slovenia (henceforth SORS); the Business Register of Slovenia (henceforth BRS); the Ministry of the Economy, and the Official Gazette of the Republic of Slovenia On-line. We describe each of these data sources below, including the variables and/or information they contain and problems, if applicable.

The PASEF database contains balance sheets and income statements for all businesses (excluding sole proprietors and the banking industry), in Slovenia from 1995 to 2003. For reasons mentioned in the introduction (most of the non-agricultural state aid has been oriented towards manufacturing, special attention paid to manufacturing), we will only use data for manufacturing firms. ${ }^{10}$ In addition to accounting data, the database contains a unique 7 -digit firm ID number, ${ }^{11}$ a 5 -digit industry code, ${ }^{12}$ information on ownership (co-operative, private, social, state, and mixed) and source of capital (domestic, foreign, or mixed) prior to 2001, the municipality and region in which the firm is located, and the average number of persons in paid employment based on hours worked. According to the Law on Enterprises, all firms that are registered in any given year are supposed to provide

\footnotetext{
${ }^{10}$ PASEF obtained the data from SORS, which collected these reports until July 2002, and from AJPES (Agency of the Republic of Slovenia for Public Legal Records and Related Services), which collected the data from July 2002 onwards.

${ }^{11}$ This 7-digit number identifies the firm uniquely. It is given to the firm at the time of its registration for the first time and may not be used for a different/new firm once the original firm ceases to exist. However, there are two exceptions: i) if firm A merges with firm B, the combined firm gets a new 7-digit ID, ii) if firm A acquires firm B, the ID of firm B ceases to exist and the new firm has the ID of firm A. Hence, we cannot keep track of mergers and acquisitions from this database.

${ }^{12}$ Refer to Table D.1 for the names of the industry codes. The classification used is NACE Rev. 3.
} 
balance sheets and income statements to the relevant government agency, regardless of whether they were in business the entire year. ${ }^{13}$

Our data on state aid for the rescue and restructuring of firms in difficulty were prepared by CSAC, and cover the period from 1998 to $2003 .{ }^{14}$ The data include registration numbers of the providing agency and aid recipient, ${ }^{15}$ date of aid approval, date of aid provision, legal foundation, documentation, legal act, instrument and purpose of aid, and the amount of state aid. The dataset has its flaws and most likely underestimates state aid to firms in difficulty, ${ }^{16}$ but according to the CSAC staff, its coverage and quality is getting better every year, and it is the best source available.

We obtain a list of firms considered to be labor intensive in 1996 from the Ministry of the Economy. Labor intensive firms had priority in the aid allocation process, so we use this list to define an indicator for these firms.

From SORS we obtain price indices and data on the registered unemployment rate by region and municipality. The producer price index (PPI) is publicly available for our sample period only at the 2-digit industry level; since 2001 SORS has also published the PPI at the 4-digit industry level, although the data are confidential in some industries due to the small number of firms. The intermediate goods price index (IGPI) and the capital goods price index (CGPI) are available only for the total economy and for Mining and Quarrying (10-14), Manufacturing (15-37), and Electricity, Gas, and Water Supply (40-41).

From the Business Register of Slovenia (BRS) we obtain data on the year in which each business was first registered (i.e., the birth of the firm). For some firms the reported birth year varies from year to year; our data assumes that the earliest reported birth year is valid. Large state firms that were broken up into smaller units also create problems; for example, a number of firms that were supposedly registered for the first time in 1999 were parts of larger firms prior to 1999, and hence are not truly entering firms. Similarly, some firms appear to exit in 1998, but were actually merged with their parent company. The detection of such firms is tedious, requires knowledge of events in Slovenia and has to be

\footnotetext{
${ }^{13}$ Firms that go into bankruptcy are required to provide this information at most 2 months after their bankruptcy. However, there are on average 5 percent of all firms every year that fail to provide their accounting information and are required to pay a fee according to the Law on Enterprises.

${ }^{14}$ Until 2003, firms in difficulty were able to obtain state aid for rescue and restructuring from a number of different agencies, depending on their circumstances. Since 2003, ME has been the only agency that can give aid to firms in difficulty (in cooperation with other agencies), which makes the state aid data more transparent.

${ }^{15}$ The latter equals the unique 7-digit firm ID number from the PASEF data.

${ }^{16}$ In earlier years when work on the database started, some aid donors kept poor or no records of the aid they gave to firms. In manufacturing, the coverage is likely to be better than in agriculture, because the ME kept quite good records from 1995 onwards and was one of the two major donors.
} 
done on a case-by-case basis. Under these circumstances, we have decided against using the actual age of firms as one of our control variables; instead, we use a dummy variable equal to 1 if a firm is at least 10 years old and 0 otherwise.

The Official Gazette of the Republic of Slovenia On-line was our resource for legislation, regulations, public tenders and other measures pertinent to state aid for the rescue and restructuring of firms in difficulty, as well as information that helped us determine whether an exiting firm actually exited or only initiated bankruptcy procedures.

\subsection{Institutional Background}

In Slovenia, state aid first became officially available after the fall of the Berlin Wall in 1989, when the country took its first steps on the path towards a market economy. Prior to 1989, firms could count on the government to save them if they got into financial trouble, though such aid was not officially called state aid.

In this paper, our focus is on the rescue and restructuring aid in manufacturing. Such aid can only be given to firms in difficulty and has officially been available since $1995 .{ }^{17}$ Until 2003, firms in difficulty were eligible to get state aid from various agencies under certain conditions, defined either in legislation or public tenders, ${ }^{18}$ and using a number of different instruments. ${ }^{19}, 20$

Conditions under which rescue and restructuring aid could be granted differed somewhat among different aid agencies. However, there were also a number of common criteria. Only medium and large firms were eligible for such aid, and these were defined using number of workers, revenue and assets (see Appendix $\mathrm{C}$ for details). Priority was given to labor

${ }^{17} \mathrm{~A}$ firm is defined to be in difficulty when it is not able, with its own resources or resources it is able to obtain from its owners/shareholders or creditors, to halt negative business trends that without state intervention would threaten the survival of the firm. Newly founded companies, companies formed through liquidation of a previous company and related companies are not entitled to rescue and restructuring aid, unless it is possible to demonstrate that the causes of the difficulties are in the enterprise itself and not the result of arbitrary reallocation of costs between them.

${ }^{18}$ We present an abbreviated version of these conditions here; more detail is available upon request.

${ }^{19}$ These instruments were: a) grants, direct interest subsidies, loan remission, b) tax deferrals, tax exemptions and relief, exemptions and relief on the payment of social security contributions, c) equity investments, conversion of debt into equity participation, d) soft loans from public and private sources, loans to companies in difficulty, e) guarantees for non-commercial and/or commercial risks, payment of guaranteed obligations, and f) other sources of aid.

${ }^{20}$ Most of the aid was given by the Ministry of the Economy (ME) and the Development Corporation of Slovenia (DCS); together, these two agencies accounted for more than 80 percent of all such aid. Other donors were the Ministry for Labor, Family and Social Affairs (MLFSA), the Employment Services of Slovenia (ESS) and the Ministry of Finance (MF). 
intensive firms, where labor intensity was defined as "employing a lot of workers who earn low wages" (according to a personal conversation with Igor Naglič from the Ministry of the Economy), rather than having a high ratio of labor to capital.

Priority was also given to firms with losses in at least two out of three consecutive years and firms with a higher share of debt financing than the industry average. ${ }^{21}$ Given that firms in difficulty required a lot of labor restructuring, priority was given to firms in regions with an above average unemployment rates or in lower development. Finally, firms with survival and growth potential were given priority, though the legislation and/or public tenders did not specify the criteria according to which potential would be judged. The selection criteria were used primarily to exclude firms from obtaining state aid, and were sometimes applied selectively based on the political preferences of the people involved in the process. However, we will establish later on that the official criteria were still relevant.

As a share of GDP, aid allocated was relatively negligible, and this share was generally decreasing over time, but the percentage of firms that received aid was far from negligible in certain sectors, as Figure 1 illustrates. In addition, these firms employed about one sixth of workers in manufacturing and also accounted for one tenth of total manufacturing output prior to 2002, as Table 1 shows. Within some 2-digit industries, more than 40 percent of workers were employed in aid-receiving firms. ${ }^{22}$

There was a sharp decrease in both the aid allocated and the number of recipients in 2002. New restrictions on state aid for the rescue and restructuring of firms in difficulty were officially adopted in July 2000. ${ }^{23}$ These restrictions were adopted to harmonize Slovenian legislation with the EU restrictions, and were part of the process by which Slovenia prepared for membership in the EU (Slovenia joined the EU on May 1, 2004). ${ }^{24}$ Under these new restrictions, aid for resolving financial problems could be granted only once, and aid for restructuring could be repeated only after ten years absent exceptional and unforeseeable circumstances over which the firm has no control. Prior to 2000, several firms in our data received aid multiple times.

\footnotetext{
${ }^{21}$ Depending on the aid program, industry was sometimes defined at the 4-digit level, and sometimes at the 2-digit level.

${ }^{22}$ The presence of aid thus also likely had an impact on the timing and magnitude of job flows, the analysis of which is not part of this paper, but will be part of future analysis.

${ }^{23}$ Decree on the purposes and conditions for the granting of state aid and on the appointment of the ministries responsible for managing individual aid schemes, The Official Gazette of the Republic of Slovenia, No. 59, 2000, June 30, 2000.

${ }^{24}$ Slovenia declared its goal of joining the EU upon its declaration of independence in 1991, it signed the European Agreement in 1996 and negotiations to join the EU officially began in 1998. Hence, changes in legislation were to be expected, and there was presumably no jump in firms' perceptions about the likelihood of Slovenia joining the EU when the actual changes in legislation on state aid occured.
} 
Other major changes occured earlier. The process of trade liberalization had begun in the Socialist Federal Republic of Yugoslavia prior to 1991, and Slovenia continued the liberalization of import regimes and the removal of import charges and numerous tariff exemptions when it became independent. The previous protection policy was nontransparent, which led to a number of undesireable outcomes, such as inefficient use of factors of production and inappropriate development of the structure of the economy. Prior to independence, Slovenian producers enjoyed high levels of protection, and nonprice measures (quotas, licenses, etc.) were extremely important. In 1986, free imports represented only 3 percent of import value; this increased to 78 percent by 1990, to 97 percent in 1993 and 98 percent in 1996 (see Majcen and Kaminski [2004], p. 137). The only exceptions in the trade liberalization process were the agriculture, food processing and textile industries. Even prior to 1991, Slovenia's major trading partners were in the EU (Germany and Italy) and a trade agreement between the EU and Slovenia was in effect by January 1, 1997; exports had never been strictly directed towards the Eastern bloc.

Table 1: Percentage of Firms that Received Aid - Manufacturing, 1998-2003

\begin{tabular}{|c|c|c|c|c|c|c|c|c|c|}
\hline \multirow[t]{2}{*}{ Year } & \multicolumn{3}{|c|}{ Received Aid } & \multicolumn{3}{|c|}{$\begin{array}{c}\text { Labor Intensive \& } \\
\text { Received Aid }\end{array}$} & \multicolumn{3}{|c|}{$\begin{array}{c}\text { Medium or Large \& } \\
\text { Received Aid }\end{array}$} \\
\hline & Firms & Labor & Output & Firms & Labor & Output & Firms & Labor & Output \\
\hline 1998 & 1.59 & 15.20 & 11.25 & 1.32 & 14.35 & 10.69 & 1.50 & 15.17 & 11.22 \\
\hline 1999 & 2.87 & 16.42 & 10.40 & 2.20 & 14.13 & 8.60 & 2.47 & 16.14 & 10.31 \\
\hline 2000 & 2.61 & 18.26 & 11.34 & 1.92 & 15.80 & 9.37 & 2.38 & 18.01 & 11.28 \\
\hline 2001 & 1.09 & 9.91 & 4.61 & 0.82 & 9.22 & 4.17 & 1.03 & 9.88 & 4.60 \\
\hline 2002 & 0.14 & 3.00 & 0.75 & 0.12 & 2.90 & 0.74 & 0.12 & 2.90 & 0.74 \\
\hline 2003 & 0.20 & 3.33 & 0.78 & 0.20 & 3.33 & 0.78 & 0.16 & 3.23 & 0.76 \\
\hline
\end{tabular}

Source: Own calculations based on CSAC and PASEF data.

Table 2: Number of Firms that Received Aid Pre- and Post-2002, Manufacturing

\begin{tabular}{ccccc}
\hline \hline & \multicolumn{2}{c}{ Size } & \multicolumn{2}{c}{ Labor Intensity } \\
\cline { 2 - 5 } & Medium or Large & Small & Labor Intensive & Non-Labor Intensive \\
\hline Pre-2002 & 354 & 37 & 300 & 91 \\
$2002-2003$ & 16 & 1 & 16 & 1 \\
\hline
\end{tabular}

Source: Own calculations based on CSAC and PASEF data.

Slovenia's labor market reform was slow and cautious. The government retained strict employment protection legislation, maintained a costly unemployment benefits system, imposed a heavy tax burden on labor (tax wedge of 48 percent), and kept minimum wages relatively high (40 percent of average wages). The 1991 Labor Code remained in power until 2003, with minor modifications, and the 2003 Labor Code still makes it hard for employers to lay off workers for "economic reasons" (see Vodopivec [2004] for more details). 
Figure 1: Percentage of Firms that Received State Aid for the Rescue and Restructuring to Firms in Difficulty by Firm Size and 2-digit Industry, 1998-2003
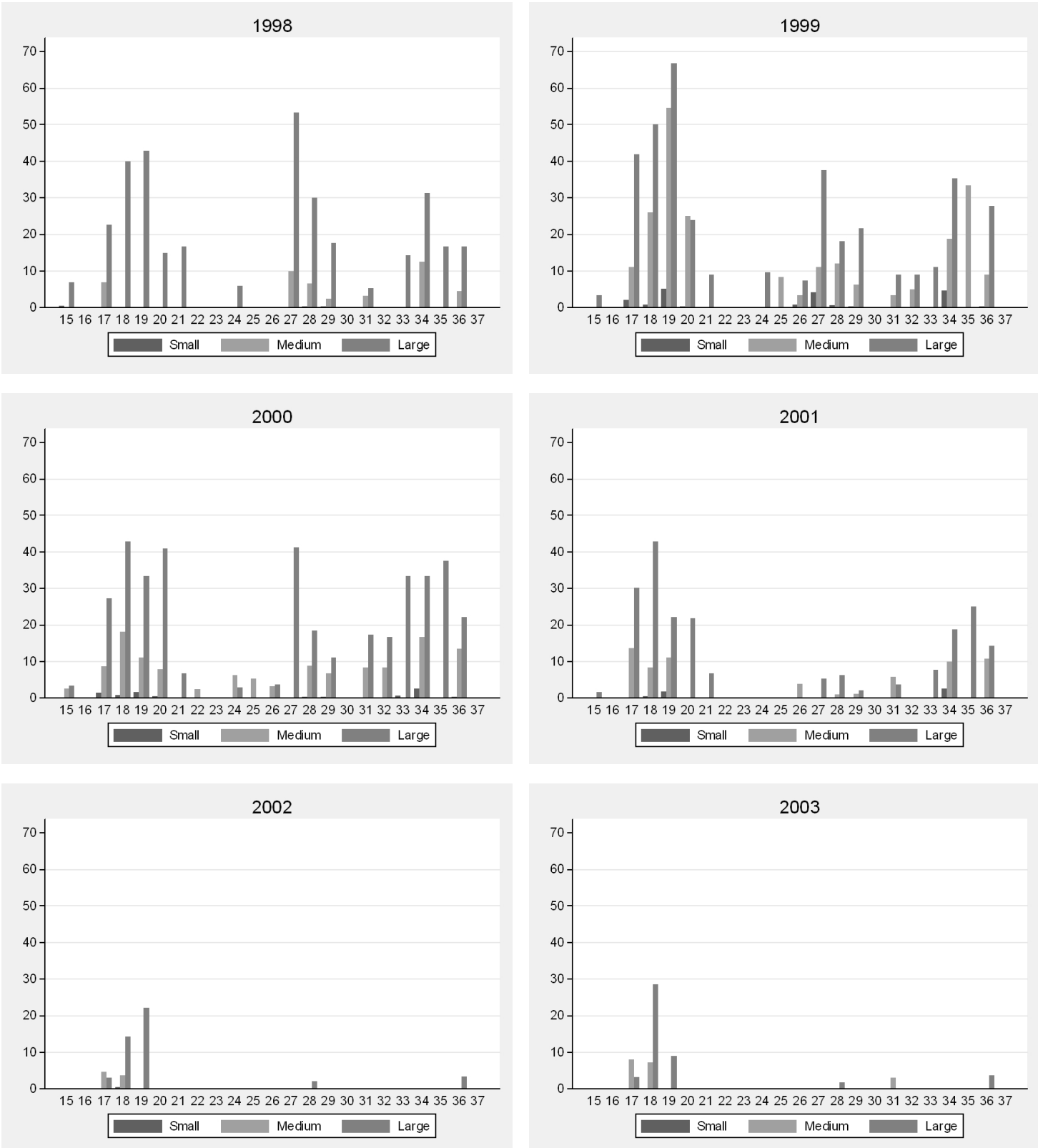

Note: Refer to Table D.1 for the names of 2-digit industries. Source: Own calculations based on CSAC and PASEF databases. 
Table 3: Ratio of Share of State Aid Received vs. Share of Output Produced by Region, 1998-2003

\begin{tabular}{lrrrrrr}
\hline \hline & \multicolumn{7}{c}{ Year } \\
\cline { 2 - 7 } Region & 1998 & 1999 & 2000 & 2001 & 2002 & 2003 \\
\hline Dolenjska & 0.038 & 0.207 & & & & \\
Gorenjska & 0.595 & 1.513 & 0.736 & 0.870 & 7.830 & 1.488 \\
Goriska & 0.155 & 0.313 & 0.648 & 0.142 & 0 & 1.490 \\
Jugovzhodna & & & 0.722 & 0.078 & 0 & 0.068 \\
Koroska & 0.474 & 2.179 & 1.208 & 0.312 & 4.931 & 0 \\
Notranjsko-kraska & 0.086 & 0.280 & 0.699 & 0 & 0 & 0 \\
Obalno-kraska & 2.180 & 0.559 & 0.173 & 0.805 & 0 & 7.662 \\
Osrednjeslovenska & 1.548 & 1.388 & 0.884 & 1.733 & 0 & 0.201 \\
Podravska & 1.239 & 0.804 & 2.928 & 1.154 & 1.027 & 0.121 \\
Pomurska & 0.141 & 0.105 & 0.274 & 0.017 & 0.401 & 9.763 \\
Savinjska & 0.133 & 0.378 & 0.599 & 0.051 & 0.010 & 0.076 \\
Spodnjeposavska & 0.934 & 0.676 & 1.235 & 0.754 & 0.058 & 1.483 \\
Zasavska & 0.180 & 1.681 & 1.409 & 0.012 & 0 & 0 \\
\hline
\end{tabular}

Source: Own calculations based on CSAC and PASEF data.

The allocation of aid also differed by region, ${ }^{25}$ as Table 3 illustrates. ${ }^{26}$ Regions that received disproportionate amounts of state aid in general had high unemployment rates (Podravska, Pomurska, Zasavska, Spodnjeposavska) and/or were underdeveloped as measured by gross value added per capita (Podravska, Zasavska, Pomurska). ${ }^{27,28}$ Regional differences in aid receipt are partly due to differences in the distribution of industry across regions. In addition, some regions were hit harder than others by the disintegration of the Socialist Republic of Yugoslavia and other political changes at the beginning of the 1990s. Hard-hit regions such as Gorenjska, Savinjska, Podravska, Koroska and Zasavska were characterized by large manufacturing firms that had problems adjusting to the market economy and finding new markets. The Pomurska region, meanwhile, has always been the least developed region in Slovenia, with mostly agricultural activity and limited opportunities even prior to the 1990s.

\footnotetext{
${ }^{25}$ The capital, Ljubljana, is located in the Osrednjeslovenska region.

${ }^{26}$ Regional classification changed in 2000. Southern parts of the Osrednjeslovenska region were classified together with the Dolenjska region as the Jugovzhodna region. Other regions remained the same. In the paper, we use the pre-2000 classification.

${ }^{27}$ Gross domestic output per capita by region would be a better measure of development, but SORS has only calculated GDP by region for 1999 and 2001, and their methodology changed in between. We have calculated gross value added per region using the entire PASEF database on all firms in Slovenia, and used the data on population by region from SORS to calculate gross value added per capita.

${ }^{28}$ Gorenjska did not have a higher than average registered uneployment rate and/or a lower than average gross value added per capita; however, the steel industry was concentrated there.
} 


\section{Estimation Methods}

Evaluating the impact of state aid on static and dynamic allocative efficiency is difficult due to the lack of a counterfactual and because of selection bias. The former asks what would have happened if the firm had been subject to an alternative policy (for example, if a firm received aid, what would have happened to its behavior if it had not received aid, and if the firm did not receive aid, what would have happened to its behavior had it received aid). The latter arises from the fact that firms that receive aid usually differ from firms that do not receive aid along other dimensions. The average treatment effect $(A T E)$ is defined as the difference of the expected outcomes with aid and without aid:

$$
A T E=E\left(Y^{1} \mid D=1\right)-E\left(Y^{0} \mid D=0\right)
$$

where $Y^{1}$ indicates outcome with aid, $Y^{0}$ indicates outcome without aid and $D$ is a binary indicator equal to 1 if a firm receives aid. This estimate includes the effect on firms for which aid was never intended. The average treatment effect on the treated $(A T T)$ focuses explicitly on the firms that received aid and is defined as:

$$
A T T=E\left(Y^{1} \mid D=1\right)-E\left(Y^{0} \mid D=1\right)
$$

Under the assumption of homogeneous treatment effects, ATT is identical to ATE, but this is not the case under the assumption of heterogeneous treatment effects (Blundell and Costa Dias [2000]).

In general, experimental evaluation is the preferred method to estimate treatment effects; however, given that firms are not assigned randomly to a group that receives aid and a control group that does not receive aid, experimental data are not available. We have to use non-experimental evaluation estimators and rely on the information on how firms actually performed after some of them received aid and others did not. Non-experimental treatment effects estimators can be grouped under two categories based on how they handle selection bias. The first category contains estimators that rely on selection on observables and the second category contains estimators explicitly allowing selection on unobservables (Caliendo and Hujer [2005]). 


\subsection{Selection on Observables}

OLS regression implicitly relies on the assumption of selection on observables. ${ }^{29}$ The equation of interest can be written as:

$$
y_{i t}=\beta_{0}+\beta_{1} A I D_{i t-1}+\mathbf{X}_{\mathbf{i t}-\mathbf{1}} \gamma+u_{i t}
$$

where $i$ denotes firm, $t$ denotes time, $y$ is the outcome variable of interest (micro covariance, growth of market share or growth of productivity), $A I D$ is a dummy variable defined according to:

$$
A I D_{i t}^{30}= \begin{cases}1 & \text { if firm receives aid in } t \\ 0 & \text { otherwise }\end{cases}
$$

and $\mathrm{X}$ is a vector of controls.

The assumption needed to identify the average treatment effect of aid is that conditioning linearly on $\mathbf{X}$ suffices to eliminate selection bias. This assumption might fail and lead to biased estimates. In our case, the direction of bias is not clear, since different scenarios are possible:

1. Self-selection among firms: applying for state aid is a time- and money-consuming process, since by law applying firms need to prepare a restructuring plan. If only inherently good firms apply, then the OLS coefficient will be biased upwards.

2. If firms that are inherently bad are more likely to seek out political connections and if connections increase the likelihood of receiving aid conditional on applying, and if firms are more likely to apply when the likelihood of success is high, the OLS coefficient will be biased downwards.

3. If the government prefers to give aid to firms that it suspects to be inherently bad, but that are located in regions with high unemployment rates and thus potential social problems, the OLS coefficient will be biased downwards.

Whether firms are inherently "good" or inherently "bad" is not observable, so estimators that account for selection on unobservables might be more appropriate.

\footnotetext{
${ }^{29}$ Another estimator assuming selection on observables is the matching estimator. It is based on an identifying assumption that conditional on $\mathbf{X}$, the outcome is independent of $A I D$, but it does not assume any particular functional forms as the linear regression model does.

${ }^{30} \mathrm{We}$ decided to use an indicator for aid instead of amounts of aid because there are a number of cases in which aid was given to a holding company, and there is no further information available on which firms within a holding company received aid.
} 


\subsection{Selection on Unobservables}

The underlying instrumental variables identification strategy is to find a variable that determines treatment participation but does not influence the outcome equation. The model can be written as:

$$
\begin{aligned}
y_{i t} & =\beta_{0}+\beta_{1} A I D_{i t-1}+\mathbf{X}_{\mathbf{i t}-\mathbf{1}} \boldsymbol{\gamma}+u_{i t} \\
A I D_{i t-1} & =\phi_{0}+\mathbf{Z}_{\mathbf{i t}-\mathbf{1}} \boldsymbol{\eta}+\mathbf{X}_{\mathbf{i t}-\mathbf{1}} \boldsymbol{\varphi}+\epsilon_{i t-1}
\end{aligned}
$$

where $\mathbf{Z}$ is a vector of instrumental variables and the rest is the same as in equation (7).

IV requires the existence of at least one independent variable $Z$ affecting $A I D$, but not directly affecting the outcome. The vector $Z$ thus has to have a non-zero coefficient in the decision rule in equation (9), and it must be uncorrelated with the error terms $u$ and $\epsilon$ given $\mathbf{X}$. A good instrument is hard to come by, since it has to predict participation, but not otherwise influence the outcome equation. If the instrument is correlated with $\epsilon$, the IV estimate will be biased. ${ }^{31}$

Our identification strategy involves using variables that affect the likelihood of getting aid prior to 2002, but not afterwards when aid became less available. These variables may be directly correlated with outcomes, but $\beta_{1}$ can still be identified as long as the direct impact of these variables on outcomes did not change in 2002. We exploit the variation in aid receipt driven by three factors: (1) differential likelihood of getting aid pre- and post2002, (2) differential likelihood of getting aid for labor intensive firms versus non-labor intensive firms, and (3) differential likelihood of getting aid for medium and large firms versus small firms. We discuss each of these factors in turn.

First, firms were more likely to get aid prior to 2002. As described in section 2.3, new restrictions on state aid were officially adopted in 2000, but they actually had a major effect on aid availability only when the largest donor, the Development Corporation of Slovenia (DCS), ceased to exist in 2002. These restrictions, as well as the closure of DCS, were "dictated" by the process of joining the EU and are hence a source of exogenous variation. However, other things changed over this period that could lead to differences in the outcomes of interest. For example, substantial changes in the Bankruptcy Code were

\footnotetext{
${ }^{31}$ Under the constant treatment effects assumption (i.e., the impact of treatment is the same for every unit in the population) the IV estimate represents a population average. In a heterogeneous treatment effects world, where the instrument is correlated with the impact and monotonicity holds, the IV estimator gives the Local Average Treatment Effect (LATE), defined as a mean impact of treatment on compliers (those who respond to the instrument by taking the treatment when they otherwise would not) (Angrist et al. [1996]).
} 
implemented in July 1999, and although that had an immediate impact on the number of bankruptcies, the response was again delayed, because the courts in Slovenia are relatively slow and therefore bankruptcy takes time. Using pre-post 2002 variation thus may not satisfy the exclusion restriction by itself.

Second, labor intensive firms were given priority in the aid allocation process, and as Table 2 shows, they were over 3 times more likely to get aid than non-labor intensive firms. Labor intensive firms were defined by the Ministry of the Economy (ME) as firms employing a lot of workers who earn low wages. We use a list of labor intensive firms dated in 1996 obtained from the ME to identify such firms in our sample. While some firms that potentially fit this criterion after 1996 are not defined as labor intensive, our definition has the advantage of keeping the measure of labor intensity free from possible whims of politicians in later years and thus free from additional selection bias. An indicator variable for labor intensive firms might be a potential instrument. However, it fails the exclusion restriction, since transition and/or competition may have induced more downsizing of labor intensive firms and thus may have had an impact on outcomes directly.

Third, medium and large firms were almost 10 times more likely to get aid than small firms. The eligibility criteria stated that only medium and large firms could receive aid, but in reality, some small firms also received it (either directly or through the holding companies to which they were related). ${ }^{32}$ An indicator variable for medium and large firms might be a potential instrument, but it fails the exclusion restriction. Existing studies show that size of firms has an impact on the likelihood of exit (for example, Baily et al. [1992] and Disney et al. [2003a]) and also indicate that size matters for allocative efficiency. ${ }^{33}$

The interaction of a pre-2002 dummy variable and an indicator for labor intensive firms, controlling for baseline differences, is a valid instrument if it has no direct effect on the outcomes of interest, which is plausible, since there are no indications that the direct effect of labor intensity should have changed pre/post 2002. Similarly, the interaction of a pre-2002 dummy variable and an indicator for medium and large firms, controlling for baseline differences, is a valid instrument, if the effect of size of firms on the outcomes of interest did not change pre/post 2002.

To summarize before proceeding to the estimation results, we define our two instru-

\footnotetext{
${ }^{32}$ In Slovenia, the firm size is defined according to the Law on Enterprises (see Appendix C for details). Since the official firm size definition changed significantly in 2002, we measure size according to the 1997 criteria to avoid blurring the impact of aid on outcomes.

${ }^{33}$ Haltiwanger and Schweiger [2005] find that in some countries, small firms have higher static allocative efficiency while in other countries, larger firms have higher static allocative efficiency.
} 
mental variables, $Z_{1}$ and $Z_{2}$, in the following way:

$$
Z_{1, i t}= \begin{cases}1 & \text { if a lab.or intensive firm \& year prior to } 2002 \\ 0 & \text { otherwise, }\end{cases}
$$

and

$$
Z_{2, i t}= \begin{cases}1 & \text { if a medium or large firm \& year prior to } 2002 \\ 0 & \text { otherwlse. }\end{cases}
$$

Before proceeding to estimation results, we need to mention that although $A I D$ is a binary variable, we use a linear probability model in the first stage and not a probit or logit model. The reason for this lies in the low incidence of aid, especially after 2002, as illustrated in Tables 1 and 2. Since the probability of receiving aid drops close to zero after 2001, maximum likelihood has a hard time identifying the coefficients on the instruments. Angrist [2001] argues that for binary endogenous regressors, "if the covariates are sparse and discrete, linear models and associated estimation techniques like 2SLS are no less appropriate for LDV's than for other kinds of dependent variables" (p. 3).

\section{$5 \quad$ Estimation Results}

\subsection{Aggregate Properties and Summary Statistics}

In aggregate terms, the static allocative efficiency of Slovenian manufacturing, calculated as a weighted average of 2-digit industry aggregate covariances terms using TFP and timeinvariant value-added weights, was positive, as Table 4 illustrates. The covariance measure remained roughly constant until 2001, when it declined by 6.8 percent, then started to improve. ${ }^{34}$

Our estimates are roughly comparable to other available estimates for Slovenia. Bartelsman et al. [2004b] find that the labor-productivity-based Olley and Pakes [1996] covariance in Slovenian manufacturing was negative from 1992-1997 and positive from 1998-2001, and that it was increasing throughout the period. Results are similar for TFP. The magnitudes differ, because their sample is only a subsample of ours, since they were interested in three- and five-year changes in productivity growth, whereas we are looking at one-year changes. In addition, we use services as one of the factors of production, whereas they only use labor, capital and materials.

\footnotetext{
${ }^{34}$ Labor productivity based covariance (not reported here, but available upon request) was positive and increasing over the period.
} 
Growth of TFP was positive from 1999 onwards (see column (4) of Table 4). De Loecker and Konings [2003] estimate the growth rate of TFP to be 0.2 percent on average in the period 1998-2001. However, they use "employment market shares" rather than "sales market shares" (p. 20) in addition to using a production function with only labor and capital as inputs, which makes it harder to compare the results. Using employment shares instead of sales shares as weights in Slovenia is bound to produce different results, since there were significant differences between the two in a number of 2-digit industries.

Column (5) of Table 4 shows the unweighted exit rates of firms in manufacturing from 1998 to 2003. The exit rate is defined as follows: ${ }^{35}$

$$
\text { exit } \text { rate }_{u w, t}=\frac{\text { No. of exiting firms between } t \text { and } t+1}{1 / 2(\text { Total no. of firms in } t-1+\text { Total no. of firms in } t)}
$$

The exit rate increased to about 2.9 percent in 1999, dropped to about 2.0 percent in 2001, and then increased again. These rates are relatively low compared to exit rates in manufacturing in most OECD and transition countries, as reported by Bartelsman et al. [2004b]. Bartelsman et al. [2004b] report the exit rate for Slovenia to be around 4 percent in manufacturing firms with at least 1 employee in the period 1992-2000. De Loecker and Konings [2003] find exit rates in the period 1998-2000 to be about 1 percentage point higher than what we report here. We trust our results more, since we were very careful in measuring true exit and did not rely solely on the availability of the accounting data, which has missing firm-year observations.

Table 4: Olley-Pakes Covariance and Exit Rates in Manufacturing, 1998-2003

\begin{tabular}{cccccc}
\hline \hline Year & $\begin{array}{c}\text { Weighted TFP } \\
(1)\end{array}$ & $\begin{array}{c}\text { Unweighted TFP } \\
(2)\end{array}$ & $\begin{array}{c}\text { Covariance } \\
(3)\end{array}$ & $\begin{array}{c}\text { TFP Growth } \\
(4)\end{array}$ & $\begin{array}{c}\text { Exit Rate } \\
(5)\end{array}$ \\
\hline 1998 & 2.819 & 2.702 & 0.117 & -0.039 & 0.024 \\
1999 & 2.825 & 2.710 & 0.115 & 0.022 & 0.029 \\
2000 & 2.875 & 2.758 & 0.117 & 0.061 & 0.028 \\
2001 & 2.894 & 2.785 & 0.109 & 0.041 & 0.020 \\
2002 & 2.907 & 2.789 & 0.118 & 0.024 & 0.022 \\
2003 & 2.935 & 2.781 & 0.155 & 0.050 & 0.029 \\
\hline
\end{tabular}

Source: Own calculations based on PASEF data.

\footnotetext{
${ }^{35}$ Since an exiting firm in $t$ exists for the last time in $t$, exiting firms exit at some time between $t$ and $(t+1)$.
} 
Table 5: Summary Statistics - Overall, by Aid Receipt and by Firm Status

\begin{tabular}{|c|c|c|c|c|c|c|c|c|c|c|c|c|}
\hline \multirow{2}{*}{$\begin{array}{l}\text { Firm-Years } \\
\text { Mean [Std. Dev.] }\end{array}$} & \multicolumn{2}{|c|}{ Overall } & \multicolumn{2}{|c|}{ Without Aid } & \multicolumn{2}{|c|}{ With Aid } & \multicolumn{2}{|c|}{ Continuers } & \multicolumn{2}{|c|}{ Entrants } & \multicolumn{2}{|c|}{ Exiters } \\
\hline & Obs & $(1)$ & Obs & $(2)$ & Obs & $(3)$ & Obs & $(4)$ & Obs & $(5)$ & Obs & $(6)$ \\
\hline & \multicolumn{12}{|c|}{ Dependent Variables (Outcomes) } \\
\hline \multirow[t]{2}{*}{ Micro Covariance (TFP) } & 29335 & 0.144 & 28927 & 0.145 & 408 & 0.105 & 27807 & 0.134 & 926 & 0.302 & 602 & 0.374 \\
\hline & & {$[1.207]$} & & {$[1.202]$} & & {$[1.514]$} & & {$[1.219]$} & & {$[0.991]$} & & [0.891] \\
\hline \multirow[t]{2}{*}{ Growth of Market Share } & 27704 & -0.011 & 27305 & -0.010 & 399 & -0.075 & 27125 & -0.003 & & & 579 & -0.392 \\
\hline & & {$[0.450]$} & & {$[0.451]$} & & {$[0.384]$} & & {$[0.439]$} & & & & {$[0.737]$} \\
\hline \multirow[t]{3}{*}{ Growth of TFP } & 27704 & 0.013 & 27305 & 0.013 & 399 & -0.003 & 27125 & 0.016 & & & 579 & -0.158 \\
\hline & & {$[0.434]$} & & {$[0.436]$} & & {$[0.255]$} & & {$[0.424]$} & & & & {$[0.762]$} \\
\hline & \multicolumn{12}{|c|}{ Explanatory Variables } \\
\hline \multirow[t]{2}{*}{ Aid } & 29335 & 0.014 & 28927 & 0 & 408 & 1 & 27807 & 0.015 & 926 & 0.002 & 602 & 0 \\
\hline & & {$[0.117]$} & & {$[0]$} & & {$[0]$} & & {$[0.120]$} & & {$[0.046]$} & & {$[0]$} \\
\hline \multirow[t]{2}{*}{ TFP } & 29335 & 2.920 & 28927 & 2.921 & 408 & 2.832 & 27807 & 2.934 & 926 & 2.662 & 602 & 2.606 \\
\hline & & {$[0.840]$} & & {$[0.841]$} & & {$[0.776]$} & & {$[0.824]$} & & {$[1.092]$} & & [1.038] \\
\hline \multirow[t]{2}{*}{ Labor Intensive Firms } & 29335 & 0.149 & 28927 & 0.140 & 408 & 0.775 & 27807 & 0.153 & 926 & 0 & 602 & 0.181 \\
\hline & & {$[0.356]$} & & {$[0.347]$} & & {$[0.418]$} & & {$[0.360]$} & & {$[0]$} & & {$[0.385]$} \\
\hline \multirow{2}{*}{$\begin{array}{l}\text { Labor Intensive Firms } \\
\text { x Pre- } 2002\end{array}$} & 29335 & 0.104 & 28927 & 0.095 & 408 & 0.735 & 27807 & 0.106 & 926 & 0 & 602 & 0.150 \\
\hline & & {$[0.305]$} & & {$[0.293]$} & & {$[0.442]$} & & {$[0.308]$} & & {$[0]$} & & {$[0.357]$} \\
\hline \multirow[t]{2}{*}{ Medium and Large Firms } & 29335 & 0.220 & 28927 & 0.210 & 408 & 0.907 & 27807 & 0.226 & 926 & 0.064 & 602 & 0.174 \\
\hline & & {$[0.414]$} & & {$[0.408]$} & & {$[0.291]$} & & {$[0.418]$} & & {$[0.244]$} & & {$[0.380]$} \\
\hline \multirow{4}{*}{$\begin{array}{l}\text { Medium and Large Firms } \\
\text { x Pre-2002 } \\
\text { Old Firms (10+ Years })\end{array}$} & 29335 & 0.139 & 28927 & 0.129 & 408 & 0.868 & 27807 & 0.143 & 926 & 0.045 & 602 & 0.130 \\
\hline & & {$[0.346]$} & & {$[0.335]$} & & {$[0.339]$} & & {$[0.350]$} & & {$[0.208]$} & & {$[0.336]$} \\
\hline & 29335 & 0.384 & 28927 & 0.382 & 408 & 0.542 & 27807 & 0.398 & 926 & 0 & 602 & 0.302 \\
\hline & & {$[0.486]$} & & {$[0.486]$} & & {$[0.499]$} & & {$[0.490]$} & & {$[0]$} & & {$[0.460]$} \\
\hline \multirow{6}{*}{$\begin{array}{l}\text { Loss in at least } 2 \text { out } \\
\text { of } 3 \text { Consecutive Years } \\
\text { Share of Debt Financing higher } \\
\text { than 4-Digit Industry Average } \\
\text { Regional Unemployment } \\
\text { Rate higher than Average }\end{array}$} & 29335 & 0.146 & 28927 & 0.142 & 408 & 0.414 & 27807 & 0.147 & 926 & 0 & 602 & 0.341 \\
\hline & & {$[0.353]$} & & [0.349] & & {$[0.493]$} & & {$[0.354]$} & & {$[0]$} & & {$[0.474]$} \\
\hline & 29335 & 0.576 & 28927 & 0.575 & 408 & 0.625 & 27807 & 0.569 & 926 & 0.692 & 602 & 0.728 \\
\hline & & {$[0.494]$} & & [0.494] & & {$[0.485]$} & & {$[0.495]$} & & {$[0.462]$} & & {$[0.446]$} \\
\hline & 29335 & 0.301 & 28927 & 0.299 & 408 & 0.434 & 27807 & 0.299 & 926 & 0.308 & 602 & 0.377 \\
\hline & & {$[0.459]$} & & {$[0.458]$} & & {$[0.496]$} & & {$[0.458]$} & & {$[0.462]$} & & {$[0.458]$} \\
\hline
\end{tabular}


Table 5: Summary Statistics - Overall, by Aid Receipt and by Firm Status (continued)

\begin{tabular}{|c|c|c|c|c|c|c|c|c|c|c|c|c|}
\hline \multirow{2}{*}{$\begin{array}{l}\text { Firm-Years } \\
\text { Mean [Std. Dev.] }\end{array}$} & \multicolumn{2}{|c|}{ Overall } & \multicolumn{2}{|c|}{ Without Aid } & \multicolumn{2}{|c|}{ With Aid } & \multicolumn{2}{|c|}{ Continuers } & \multicolumn{2}{|c|}{ Entrants } & \multicolumn{2}{|c|}{ Exiters } \\
\hline & Obs & $(1)$ & Obs & $(2)$ & Obs & $(3)$ & Obs & $(4)$ & Obs & $(5)$ & Obs & $(6)$ \\
\hline & \multicolumn{12}{|c|}{ Dependent Variables (Outcomes) } \\
\hline Percentage of Regional Labor & 29335 & 0.122 & 28927 & 0.110 & 408 & 0.985 & 27807 & 0.125 & 926 & 0.049 & 602 & 0.106 \\
\hline Force Employed by the Firm & & {$[0.657]$} & & {$[0.579]$} & & {$[2.560]$} & & {$[0.670]$} & & {$[0.028]$} & & {$[0.364]$} \\
\hline
\end{tabular}

Source: Own calculations based on CSAC and PASEF data. 
Table 5 shows summary statistics of the variables used in the estimation for the overall sample, by aid receipt and by firm status. We define a dummy variable equal to 1 if the firm-level share of debt financing (the ratio of the sum of long-term provisions, long-term financial liabilities, current liabilities and accrued costs, expenses and deferred revenues to the sum of total liabilities and equity) is higher than the firm's 4-digit industry average and equal to 0 otherwise. We measure the importance of firm in its region as the firm's percentage of total regional employment.

The standard deviation of the micro covariance is very high relative to its mean (the coefficient of variation is 8.38 overall, 8.28 in firm-years with aid and 14.42 in firm-years without aid). The growth rate of market share is on average negative, but more so for firm-years with aid. TFP growth, on the other hand, is positive for firm-years without aid and negative for firm-years with aid. The standard deviations of these variables indicate that there is a lot of heterogeneity among firms.

TFP is on average higher for firm-years without aid. 77.5 percent of firm-years with aid are labor intensive, compared to 14 percent of firm-years without aid. 90.7 percent of firm-years with aid occur in medium or large firms, compared to 21 percent of firm-years without aid. Percentages of old firms, firms with losses in at least 2 out of 3 consecutive years and firms with a higher share of debt financing than the 4-digit industry average are higher for firm-years with aid. 43.4 percent of firm-years with aid are located in regions with a higher than average unemployment rate, and these firms also employ a higher percentage of their region's labor force.

Summary statistics for continuing, entering and exiting firms are shown in columns (4)-(6) of Table 5. It is interesting to note that both entering and exiting firms have a higher micro covariance than continuing firms, and there is also less heterogeneity among them in that respect (the coefficient of variation is 3.28 for entering firms and 2.38 for exiting firms, compared to 9.09 for continuing firms). Growth of market share is close to zero for continuing firms; it is significantly lower for exiting firms. Exiting firms also have lower TFP growth and lower TFP on average, though there is a lot of heterogeneity among them. The share of labor intensive firms is a bit higher among exiting firms than among continuing firms, but the share of medium and large as well as old firms is smaller. 34.1 percent of exiting firms have losses in at least 2 out of 3 consecutive years, and they have more debt than continuing and entering firms. Exiting firms are more likely to be located in regions with a higher than average uneployment rate. Overall, Table 5 shows that there is substantial heterogeneity among firms.

As explained in Section 4, we estimate the impact of state aid on allocative efficiency, controlling for two digit industry, region, year, and the growth rates of 2-digit industry 
output and regional gross value added in all estimations. Coefficients on industry, region, calendar year and growth rates are not reported to save space, but are available upon request. In all estimations, standard errors are clustered at the firm identification number level to take into account the panel nature of the data. Explanatory variables are lagged one period in Tables $6,7,8$ and 9 .

\subsection{Impact of State Aid on Exit Decisions}

As shown in column (5) of Table 4, exit rates were relatively low in Slovenia. The exit margin was thus not the one where the bulk of the reallocation happened. Due to the fact that none of the aid-receiving firms exited during 1998-2003, we cannot estimate the impact of state aid on exit decisions directly. However, we can estimate the probability of exit using a probit model of exit on a sample of firm-years without aid and then use the estimated coefficients to calculate the predicted probability of exit for firm-years with aid based on their fundamentals. The gap between this implied probability and the actual (zero) incidence of exit among firms receiving aid will reveal something about the impact of aid on exit. Average marginal effects from estimating a probit model are shown in Table 6.

The estimated coefficients are in general in line with the predictions from the theories of market selection and other empirical studies: more productive firms and medium and large firms are less likely to exit, whereas firms with consecutive losses are more likely to exit. Economic fundamentals thus did matter in the firm decision to exit. However, the predicted probability of exit is 2.5 percent for firm-years without aid and 3.6 percent for firm-years with aid. This result indicates that according to their economic fundamentals these firms were more likely candidates for exit, but they did not exit, suggesting that aid delayed exit and kept inefficient firms alive.

\subsection{Impact of State Aid on Static Allocative Efficiency}

Regression (1) in Table 7 is based on OLS estimation of the following version of equation (7),

$$
\frac{\Delta s_{i t, j}}{\bar{s}_{t, j}} \Delta p_{i t, j}=\beta_{0}+\beta_{1} A I D_{i t-1}+\mathbf{X}_{\mathbf{i t}-\mathbf{1}} \gamma+u_{i t}
$$

where $i$ denotes firm, $t$ denotes time, $\frac{\Delta s_{i t, j}}{\bar{s}_{t, j}} \Delta p_{i t, j}$ is a measure of static allocative efficiency, $A I D$ is a dummy variable equal to 1 if firm receives aid and 0 otherwise, and $\mathbf{X}$ is a vector of controls. These estimates assume selection on observables. 
Table 6: Exit Estimation, Average Marginal Effects

\begin{tabular}{lr}
\hline \hline & Exit \\
\hline TFP & $-0.012^{* * *}$ \\
& {$[0.001]$} \\
Labor Intensive Firms & $0.026^{* * *}$ \\
& {$[0.008]$} \\
Medium and Large Firms & $-0.014^{* * *}$ \\
& {$[0.004]$} \\
Old Firms (10+ Years) & -0.003 \\
& {$[0.002]$} \\
Loss in at least 2 out of & $0.030^{* * *}$ \\
3 Consecutive Years & {$[0.004]$} \\
Share of Debt Financing higher & $0.013^{* * *}$ \\
than 4-Digit Industry Average & {$[0.002]$} \\
Percentage of Regional Labor & -0.001 \\
Force Employed by the Firm & {$[0.001]$} \\
Regional Unemployment Rate & -0.002 \\
Higher than Average & {$[0.010]$} \\
\hline Observations & 23836 \\
Firms & 5812 \\
\hline Clustered standard errors in brackets. Control variables: 2-digit industry and \\
growth of its output, region and growth of regional GVA, year. ${ }^{*}$ significant \\
at 10\%, ${ }^{* *}$ significant at $5 \%,{ }^{* * *}$ significant at 1\%. \\
\hline Predicted probability of exit for firm-years without aid \\
Predicted probability of exit for firm-years with aid \\
\hline
\end{tabular}

Source: Own calculations based on CSAC and PASEF data.

Aid has a negative and significant impact on static allocative efficiency: receipt of aid is associated with a 0.29 percent drop in micro covariance. ${ }^{36}$ This is consistent with the notion that state aid hinders the efficient allocation of resources to more productive businesses.

IV estimates in column (2) of Table 7 allows for selection on unobservables and use the interactions between a pre-2002 dummy variable and dummy variables for labor intensive firms and for medium and large firms as instrumental variables for AID. They are based

\footnotetext{
${ }^{36}$ We obtain this magnitude by dividing the estimated coefficient by the standard deviation of micro covariance from Table 5, and multiplying the result by 0.01 .
} 
on:

$$
\begin{gathered}
\frac{\Delta s_{i t, j}}{\bar{s}_{t, j}} \Delta p_{i t, j}=\beta_{0}+\beta_{1} A I D_{i t-1}+\mathbf{X}_{\mathbf{i t}-\mathbf{1}} \boldsymbol{\gamma}+u_{i t} \\
A I D_{i t-1}=\phi_{0}+\mathbf{Z}_{\mathbf{i t}-\mathbf{1}} \boldsymbol{\eta}+\mathbf{X}_{\mathbf{i t}-\mathbf{1}} \boldsymbol{\varphi}+\epsilon_{i t}
\end{gathered}
$$

The IV estimate of the coefficient on aid in column (2) of Table 7 is negative and statistically significant, and is almost 4 times higher than the OLS estimate: receipt of aid is associated with a 1.09 percent drop in micro covariance. This result indicates that the OLS estimate of the impact of aid (column (1)) is biased towards zero.

The first stage estimates, reported in column (2a) of Table 7 , indicate that firms with losses in at least two out of three consecutive years, firms whose share of debt financing is higher than their 4-digit industry average and firms employing a higher percentage of their region's labor force were more likely to get aid, as were labor intensive and medium and large firms prior to 2002. This is an important result in itself, because it indicates that the allocation of aid was not "ad-hoc" and that official criteria were followed. The instruments are significant, have the expected sign, and are uncorrelated with the error process (i.e., the joint hypotheses of correct model specification and the orthogonality conditions cannot be rejected).

The micro covariance measure depends on both the productivity and market share of the firm, so a logical next step is to separate these two channels. However, we do not run regressions with levels of productivity or market share or their deviations from industry averages as dependent variables. Due to the nature of unobserved heterogeneity, it would be much harder to achieve identification for such regressions using levels. This is especially true in the case of market shares. In the following two sections, we look at the impact of aid on the growth of market share and on the growth of TFP instead to learn more about the channel through which aid affects static allocative efficiency.

\subsection{Impact of Aid on Growth of Market Share}

The regression in column (1) of Table 8 is based on the following version of equation (7):

$$
\frac{s_{i t, j}-s_{i t-1, j}}{0.5 *\left(s_{i t, j}+s_{i t-1, j}\right)}=\beta_{0}+\beta_{1} A I D_{i t-1}+\mathbf{X}_{\mathbf{i t}-\mathbf{1}} \gamma+u_{i t}
$$


Table 7: Static Allocative Efficiency Estimation: OLS and IV

\begin{tabular}{|c|c|c|c|}
\hline & \multirow{2}{*}{$\begin{array}{l}\text { OLS } \\
(1)\end{array}$} & \multicolumn{2}{|r|}{ IV } \\
\hline & & $(2)$ & $\begin{array}{c}(2 \mathrm{a}) \\
1^{\text {st }} \text { stage: Aid }\end{array}$ \\
\hline \multirow[t]{2}{*}{ Constant } & -0.008 & -0.033 & $-0.029^{* * *}$ \\
\hline & {$[0.046]$} & {$[0.048]$} & [0.004] \\
\hline \multirow{2}{*}{ Aid } & $-0.355^{* * *}$ & $-1.315^{* * *}$ & \\
\hline & {$[0.131]$} & {$[0.508]$} & \\
\hline \multirow[t]{2}{*}{ Labor Intensive Firms } & -0.206 & -0.172 & 0.001 \\
\hline & {$[0.126]$} & {$[0.132]$} & {$[0.004]$} \\
\hline Labor Intensive Firms & & & $0.040^{* * *}$ \\
\hline x Pre-2002 & & & {$[0.010]$} \\
\hline Medium and Large Firms & $\begin{array}{r}0.496^{* * *} \\
{[0.113]}\end{array}$ & $\begin{array}{r}0.526^{* * *} \\
{[0.112]}\end{array}$ & $\begin{array}{r}-0.002 \\
{[0.002]}\end{array}$ \\
\hline Medium and Large Firms & & & $0.045^{* * *}$ \\
\hline x Pre-2002 & & & {$[0.007]$} \\
\hline \multirow{2}{*}{ Old Firms (10+ Years) } & 0.059 & 0.064 & 0.004 \\
\hline & {$[0.040]$} & {$[0.040]$} & {$[0.003]$} \\
\hline Loss in at least 2 out of & 0.035 & $0.059^{* *}$ & $0.024^{* * *}$ \\
\hline 3 Consecutive Years & {$[0.030]$} & {$[0.030]$} & {$[0.004]$} \\
\hline Share of Debt Financing higher & $-0.056^{* *}$ & $-0.052^{*}$ & $0.004^{* *}$ \\
\hline than 4-Digit Industry Average & {$[0.027]$} & {$[0.027]$} & {$[0.002]$} \\
\hline Percentage of Regional Labor & 0.183 & 0.199 & $0.017^{* * *}$ \\
\hline Force Employed by the Firm & {$[0.141]$} & {$[0.141]$} & {$[0.004]$} \\
\hline Regional Unemployment Rate & $0.117^{*}$ & 0.111 & -0.001 \\
\hline Higher than Average & {$[0.068]$} & {$[0.069]$} & [0.009] \\
\hline Observations & 23226 & 23226 & 23226 \\
\hline Firms & 5558 & 5558 & 5558 \\
\hline R-squared & 0.05 & & 0.11 \\
\hline Partial R-squared & & & 0.011 \\
\hline F-test & & & 69.06 \\
\hline p-value of Hansen J statistic & & 0.152 & \\
\hline $\begin{array}{l}\text { Clustered standard errors in brac } \\
\text { growth of its output, region anc } \\
\text { at } 10 \%,{ }^{* *} \text { significant at } 5 \%,{ }^{* * *} \mathrm{si}\end{array}$ & kets. Cont & ol variable & $\begin{array}{l}\text { digit industry and } \\
\text { year. }{ }^{*} \text { significant }\end{array}$ \\
\hline
\end{tabular}

Source: Own calculations based on CSAC and PASEF data.

where $i$ denotes firm, $t$ denotes time, $A I D$ is a dummy variable defined as in (8), and $\mathrm{X}$ is a vector of controls. The OLS specification assumes selection on observables. The estimated OLS coefficient on $A I D$ is positive, but insignificant. Estimated coefficients on the indicators for labor intensive firms, old firms, firms with losses in 2 out of 3 consecutive 
years firms whose share of debt financing is higher than their 4-digit industry average are all negative and significant, while the estimated coefficient on the indicator for medium and large firms is positive and significant.

Table 8: Growth of Market Share Estimation: OLS and IV

\begin{tabular}{|c|c|c|c|}
\hline & OLS & & IV \\
\hline & $(1)$ & $(2)$ & $(2 \mathrm{a})$ \\
\hline & & & $1^{s t}$ stage: Aid \\
\hline Constant & $0.071^{* * *}$ & $0.087^{* * *}$ & $-0.029^{* * *}$ \\
\hline & {$[0.017]$} & {$[0.017]$} & {$[0.004]$} \\
\hline Aid & 0.012 & $0.616^{* * *}$ & \\
\hline & {$[0.020]$} & {$[0.184]$} & \\
\hline Labor Intensive Firms & $-0.043^{* * *}$ & $-0.064^{* * *}$ & 0.001 \\
\hline & {$[0.011]$} & {$[0.013]$} & {$[0.004]$} \\
\hline Labor Intensive Firms & & & $0.040^{* * *}$ \\
\hline x Pre-2002 & & & {$[0.010]$} \\
\hline Medium and Large Firms & $0.032^{* * *}$ & 0.013 & -0.002 \\
\hline & {$[0.009]$} & {$[0.011]$} & {$[0.002]$} \\
\hline Medium and Large Firms & & & $0.045^{* * *}$ \\
\hline x Pre-2002 & & & {$[0.007]$} \\
\hline Old Firms $(10+$ Years $)$ & $-0.066^{* * *}$ & $-0.070^{* * *}$ & 0.004 \\
\hline & {$[0.007]$} & {$[0.007]$} & {$[0.003]$} \\
\hline Loss in at least 2 out of & $-0.086^{* * *}$ & $-0.101^{* * *}$ & $0.024^{* * *}$ \\
\hline 3 Consecutive Years & {$[0.010]$} & {$[0.011]$} & {$[0.004]$} \\
\hline Share of Debt Financing higher & $-0.013^{* *}$ & $-0.016^{* *}$ & $0.004^{* *}$ \\
\hline than 4-Digit Industry Average & {$[0.006]$} & {$[0.006]$} & {$[0.002]$} \\
\hline Percentage of Regional Labor & 0.001 & $-0.009^{*}$ & $0.017^{* * *}$ \\
\hline Force Employed by the Firm & {$[0.003]$} & {$[0.005]$} & {$[0.004]$} \\
\hline Regional Unemployment Rate & 0.006 & 0.010 & -0.001 \\
\hline Higher than Average & {$[0.040]$} & {$[0.040]$} & [0.009] \\
\hline Observations & 23182 & 23182 & 23182 \\
\hline Firms & 5549 & 5549 & 5549 \\
\hline R-squared & 0.02 & & 0.11 \\
\hline Partial R-squared & & & 0.011 \\
\hline F-test & & & 69.05 \\
\hline p-value of Hansen J statistic & & 0.174 & \\
\hline $\begin{array}{l}\text { Clustered standard errors in brac } \\
\text { growth of its output, region and } \\
\text { at } 10 \%,{ }^{* *} \text { significant at } 5 \%,{ }^{* * *} \text { si }\end{array}$ & $\begin{array}{l}\text { kets. Cont } \\
\text { growth of }\end{array}$ & $\begin{array}{l}\text { l variabl } \\
\text { egional }\end{array}$ & $\begin{array}{l}\text { digit industry and } \\
\text { year. *significant }\end{array}$ \\
\hline
\end{tabular}

Source: Own calculations based on CSAC and PASEF data.

The IV estimates in column (2) of Table 8 use the interactions between a pre-2002 
dummy variable and a dummy variables for labor intensive firms and for medium and large firms as instruments for aid. The IV estimate of the coefficient on aid is positive and statistically significant, and the point estimate is much larger than that obtained under the assumption of selection on observables. This suggests that aid receiving firms had higher market share growth than they would have had had they not received aid. The instruments are significant and have the expected sign, and the instruments are uncorrelated with the error process (i.e., the joint hypotheses of correct model specification and the orthogonality conditions cannot be rejected).

\subsection{Impact of Aid on Growth of TFP}

TFP is another channel through which static allocative efficiency can be affected by aid. The regression reported in column (1) of Table 9 is based on the following version of equation (7):

$$
p_{i t}-p_{i t-1}=\beta_{0}+\beta_{1} A I D_{i t-1}+\mathbf{X}_{\mathbf{i t}-\mathbf{1}} \boldsymbol{\gamma}+u_{i t},
$$

where $i$ denotes firm, $t$ denotes time, $p$ is firm-level TFP, $A I D$ is a dummy variable defined as in (8), and $\mathbf{X}$ is a vector of controls. The OLS specification assumes selection on observables. The estimated OLS coefficient on AID is positive, but statistically insignificant. Estimated coefficients on indicators for old firms and firms with losses in 2 out of 3 consecutive years are negative and statistically significant, while the estimated coefficient on the percentage of the regional labor force employed by the firm is positive and significant.

The IV estimate of the coefficient on aid, reported in column (2), is negative and lower than that obtained under the assumption of selection on observables but is statistically insignificant. The joint hypotheses of correct model specification and the orthogonality conditions cannot be rejected. Overall, these results suggest that aid did not have a significant effect on TFP growth.

\subsection{Summary of Results and Macroeconomic Implications}

Table 10 contains the estimates of the coefficient on aid in the models with micro covariance, growth of market share and growth of TFP as outcomes, using the OLS and IV estimators. ${ }^{37}$ Both estimation methods yield a negative and statistically significant impact of aid on micro

\footnotetext{
${ }^{37}$ For the IV estimator, we present results using both instruments mentioned in section 4.2 , and the results are similar in both magnitude and level of significance if only one of them is used.
} 
Table 9: Growth of TFP Estimation: OLS and IV

\begin{tabular}{|c|c|c|c|}
\hline & \multirow{2}{*}{$\begin{array}{l}\text { OLS } \\
(1)\end{array}$} & \multicolumn{2}{|r|}{ IV } \\
\hline & & $(2)$ & $\begin{array}{c}(2 \mathrm{a}) \\
1^{\text {st }} \text { stage: Aid }\end{array}$ \\
\hline Constant & $\begin{array}{r}-0.022^{* *} \\
{[0.011]}\end{array}$ & $\begin{array}{r}-0.025^{* *} \\
{[0.012]}\end{array}$ & $\begin{array}{r}-0.029^{* * *} \\
{[0.004]}\end{array}$ \\
\hline Aid & $\begin{array}{r}0.003 \\
{[0.012]}\end{array}$ & $\begin{array}{l}-0.119 \\
{[0.153]}\end{array}$ & \\
\hline Labor Intensive Firms & $\begin{array}{r}0.004 \\
{[0.007]}\end{array}$ & $\begin{array}{r}0.009 \\
{[0.009]}\end{array}$ & $\begin{array}{r}0.001 \\
{[0.004]}\end{array}$ \\
\hline $\begin{array}{l}\text { Labor Intensive Firms } \\
\text { x Pre-2002 }\end{array}$ & & & $\begin{array}{r}0.040^{* * *} \\
{[0.010]}\end{array}$ \\
\hline Medium and Large Firms & $\begin{array}{r}0.005 \\
{[0.006]}\end{array}$ & $\begin{array}{r}0.009 \\
{[0.008]}\end{array}$ & $\begin{array}{l}-0.002 \\
{[0.002]}\end{array}$ \\
\hline $\begin{array}{l}\text { Medium and Large Firms } \\
\text { x Pre-2002 }\end{array}$ & & & $\begin{array}{r}0.045^{* * *} \\
{[0.007]}\end{array}$ \\
\hline Old Firms (10+ Years) & $\begin{array}{r}-0.019^{* * *} \\
{[0.006]}\end{array}$ & $\begin{array}{r}-0.018^{* * *} \\
{[0.006]}\end{array}$ & $\begin{array}{r}0.004 \\
{[0.003]}\end{array}$ \\
\hline $\begin{array}{l}\text { Loss in at least } 2 \text { out } \\
\text { of } 3 \text { Consecutive Years }\end{array}$ & $\begin{array}{r}-0.024^{* * *} \\
{[0.009]}\end{array}$ & $\begin{array}{r}-0.021^{* *} \\
{[0.010]}\end{array}$ & $\begin{array}{r}0.024^{* * *} \\
{[0.004]}\end{array}$ \\
\hline $\begin{array}{l}\text { Share of Debt Financing higher } \\
\text { than 4-Digit Industry Average }\end{array}$ & $\begin{array}{r}0.005 \\
{[0.005]}\end{array}$ & $\begin{array}{r}0.006 \\
{[0.005]}\end{array}$ & $\begin{array}{l}0.004^{* *} \\
{[0.002]}\end{array}$ \\
\hline Percentage of Regional Labor & $0.004^{* *}$ & $0.006^{* * *}$ & $0.017^{* * *}$ \\
\hline Force Employed by the Firm & {$[0.002]$} & {$[0.003]$} & {$[0.004]$} \\
\hline Regional Unemployment Rate & -0.026 & -0.027 & -0.001 \\
\hline Higher than Average & [0.034] & {$[0.034]$} & [0.009] \\
\hline Observations & 23182 & 23182 & 23182 \\
\hline Firms & 5549 & 5549 & 5549 \\
\hline R-squared & 0.01 & & 0.10 \\
\hline Partial R-squared & & & 0.011 \\
\hline F-test & & & 69.05 \\
\hline p-value of Hansen J statistic & & 0.956 & \\
\hline $\begin{array}{l}\text { Clustered standard errors in brac } \\
\text { growth of its output, region anc } \\
\text { at } 10 \%,{ }^{* *} \text { significant at } 5 \%,{ }^{* * *} \mathrm{si}\end{array}$ & $\begin{array}{l}\text { kets. Cont } \\
\text { growth of } \\
\text { gnificant a }\end{array}$ & ol variable & $\begin{array}{l}\text { digit industry and } \\
\text { year. *significant }\end{array}$ \\
\hline
\end{tabular}

Source: Own calculations based on CSAC and PASEF data.

covariance. However, the IV point estimate is much larger than the OLS point estimate. ${ }^{38}$

\footnotetext{
${ }^{38}$ The results are in general similar for labor productivity-based measures (available upon request), but given the measurement problems described in Appendix B, we prefer TFP-based measures.
} 
Table 10: Summary of Results: Estimated Treatment Effects of Aid

\begin{tabular}{lrr}
\hline \hline & OLS & IV \\
\hline Micro Covariance & $-0.355^{* * *}$ & $-1.315^{* * *}$ \\
& {$[0.131]$} & {$[0.508]$} \\
Growth of Market Share & 0.012 & $0.616^{* * *}$ \\
& {$[0.020]$} & {$[0.184]$} \\
Growth of TFP & 0.003 & -0.119 \\
\multicolumn{3}{c}{ Clustered standard errors in brackets. Control variables: $2-$} \\
digit industry and growth of its output, region and growth \\
of regional GVA, year. ${ }^{*}$ significant at 10\%, ${ }^{* *}$ significant at \\
$5 \%,{ }^{* * *}$ significant at $1 \%$.
\end{tabular}

Source: Own calculations based on CSAC and PASEF data.

The IV estimator allows selection on unobservables and is as such preferable to the OLS estimator, since the process of aid allocation is not completely transparent and it is likely that some unobserved factors affecting aid receipt also affect outcomes. Correcting for selection is thus important.

The IV estimates indicate that aid had a negative impact on static allocative efficiency, and it could be that the restricted availability of aid after 2002 was behind the improvement in the Olley and Pakes [1996] covariance, beginning in 2002 (see column (4) of Table 4).

It appears that aid had an impact on the micro covariance through its impact on market shares, and not so much through productivity. With the observed zero exit rate of firms that received aid, this suggests that aid prolonged the life span of these firms, and enabled them to have higher market shares than they would have had otherwise. In short, aid for rescue and restructuring of firms appears to have been distortive. Recent events indicate that it might have been better to "pull the plug" earlier on weak firms in industries such as textiles, clothing and leather, prior to being "forced" to do so by the $\mathrm{EU}$, in order to give workers a better chance of finding new jobs elsewhere, or to start their own businesses or acquire new qualifications (Damijan and Polanec [2003], Damijan [2003], Grgič [2005]). Our estimates appear to be in accordance with this view.

To estimate the impact of state aid on aggregate allocative efficiency, a general equilibrium model is needed, taking into account the fact that in the absence of aid less productive firms would not be able to keep their market share and would eventually exit, and more productive firms would be able to grow faster. At this point, this is beyond the scope of this paper and is intended for future work. However, to give some idea, we use the coefficients 
from column (2) in Table 7 to create two counterfactuals: one in which all the firms receive aid and one in which none do.

Table 11 shows the "simulated" aggregate covariance term from the Olley and Pakes [1996] decomposition of aggregate productivity under the assumptions of no firms receiving aid, all firms receiving aid and the actual number of firms receiving aid (see Table 1 for details on the percentage of firms that received aid). If everyone receives aid, the impact on the aggregate covariance term is enormous compared to the case in the absence of aid. Using the actual aid-receiving firms, the aggregate covariance term is about 1 to 30 percent lower than the no-aid aggregate covariance, depending on the year.

Table 11: Aggregate Static Allocative Efficiency in Manufacturing under Different Assumptions on Who Receives Aid, 1999-2003

\begin{tabular}{cccc}
\hline \hline & \multicolumn{3}{c}{ Percentage of Firms Receiving Aid } \\
\cline { 2 - 4 } Year & 0 & 100 & Actual \\
\hline 1999 & 0.128 & -1.129 & 0.101 \\
2000 & 0.136 & -1.115 & 0.092 \\
2001 & 0.140 & -1.123 & 0.102 \\
2002 & 0.138 & -1.098 & 0.126 \\
2003 & 0.143 & -1.099 & 0.141 \\
\hline
\end{tabular}

Source: Own calculations based on CSAC and PASEF data and Table 7.

\section{Conclusion}

The literature on the effect of institutions on firm performance is relatively small, because micro level data on both firm performance and market institutions are not widely available. In this paper, we use a unique census micro level data set on a potentially very distortive market institution, namely state aid for firms in difficulty. We examine its impact on the static and dynamic allocative efficiency of Slovenian manufacturing in the period from 1998-2003.

We use an Olley and Pakes [1996]-inspired measure of static allocative efficiency, which takes into account both productivity and the allocation of inputs and outputs across businesses. This measure is comparable across firms and sectors, and it provides an informative and compact measure of allocative efficiency that could be used by policy makers when allocating aid to firms. Even though Slovenia is among the most successful transition economies, analysis reveals that aid had a negative and significant impact on static allocative efficiency. 
Aid also appears to have postponed the exit of firms, since none of the firms that received aid exited, even though the predicted mean probability of exit based on fundamentals was higher for receipients than for firms that did not receive aid. The growth rate of market share was higher for aid-receiving firms, which suggests that aid had a distortive effect on the market structure, because it allowed less efficient firms to grow faster than more efficient firms and thus shifted the burden of structural adjustment onto firms that managed without aid.

To estimate the impact of state aid on aggregate allocative efficiency and productivity growth, a general equilibrium model is needed, taking into account the fact that in the absence of aid less productive firms would not be able to keep their market share and would eventually exit, while more productive firms would be able to grow faster. This is beyond the scope of this paper and is intended for future work. Future work also includes looking at the impact of state aid on investment and job flows, given that aid-receiving firms employed up to 18 percent of all workers in manufacturing.

There are a couple of limitations that need to be mentioned. First, these estimates assume homogenous treatment effects (i.e., the impact of aid is assumed to be constant across firms). While this may be appropriate as a first step in the direction of studying the treatment effects of aid, we plan to relax this assumption and allow the impact of aid to differ across firms (at least for treated and untreated firms). Second, the impact of aid might depend on where the firm is in the distribution of productivity or micro covariance. Since only a small percentage of firms actually received aid, however, the data do not allow the estimation of more sophisticated models, such as a quantile regression model, for example. Third, the period of analysis is relatively short.

Working with firm-level datasets presents many challenges, since such data usually have restricted access and are not readily available or even prescreened for errors as some household level datasets are. There is a lot of heterogeneity among firms. Missing firm-year observations and measurement error are part and parcel of every firm-level dataset and the quality of estimates critically depends on the way these are dealt with. In addition, aid affected only a small number of firms, and estimating treatment effects pushes the data quite hard. However, it is an instructive exercise and in time, the quality of micro level data on both firms and institutional measures is likely to improve as we learn more about both. 


\section{References}

Joshua D. Angrist. Estimation of Limited Dependent Variable Models With Dummy Endogenous Regressors: Simple Strategies for Empirical Practice. Journal of Business 6 Economic Statistics, 19(1):2-16, 2001.

Joshua D. Angrist, Guido W. Imbens, and Donald B. Rubin. Identification of Causal Effects Using Instrumental Variables. Journal of the American Statistical Association, 91(434): 444-455, June 1996.

Martin Neil Baily, Charles Hulten, and David Campbell. Productivity Dynamics in Manufacturing Plants. Brookings Papers on Economic Activity. Microeconomics, pages 187249, 1992.

John R. Baldwin. The Dynamics of Industrial Competition. Cambridge University Press, New York, 1995.

John R. Baldwin and P. K. Gorecki. Entry, Exit and Productivity Growth. In Paul A. Geroski and Joachim Schwalbach, editors, Entry and Market Contestability: An International Comparison, pages 244-256. Blackwell, Oxford, 1991.

Eric J. Bartelsman, John C. Haltiwanger, and Stefano Scarpetta. Distributed Analysis of Firm-level Data from Industrial and Developing Countries. Mimeo, 2004a.

Eric J. Bartelsman, John C. Haltiwanger, and Stefano Scarpetta. Microeconomic Evidence of Creative Destruction in Industrial and Developing Countries. Working Paper 3464, World Bank, December 2004b.

Eric J. Bartelsman, John C. Haltiwanger, and Stefano Scarpetta. Measuring and Analyzing Cross-Country Differences in Firm Dynamics. Mimeo, 2005.

Richard Blundell and Monica Costa Dias. Evaluation Methods for Non-Experimental Data. Fiscal Studies, 21(4):427-468, 2000.

Ricardo J. Caballero and Mohamad L. Hammour. The Cleansing Effect of Recessions. American Economic Review, 84(5):1356-1368, 1994.

Ricardo J. Caballero and Mohamad L. Hammour. Institutions, Restructuring, and Macroeconomic Performance. Working Paper 7720, NBER, May 2000.

Marco Caliendo and Reinhard Hujer. The Microeconometric Estimation of Treatment Effects - An Overview. Discussion Paper 1653, IZA, July 2005. 
Commission of the EC. State Aid Scoreboard - Spring 2004 Update. Report, Commission of the EC, 2004. $\operatorname{COM}(2004) 256$ final.

Jože P. Damijan. Socialne subvencije in razvojna beda (Social Subsidies and Developmental Misery). Finance, December 16, 2003. In Slovenian lanugage.

Jože P. Damijan and Sašo Polanec. Z Alpino v socializem (With Alpina into Socialism). Finance, October 14, 2003. In Slovenian lanugage.

Stephen J. Davis, John C. Haltiwanger, and Scott Schuh. Job Creation and Destruction. The MIT Press, Cambridge, Massachusetts, 1996. 260 pages.

Jan De Loecker and Jozef Konings. Creative Destruction and Productivity Growth in an Emerging Economy: Evidence from Slovenian Manufacturing. Discussion Paper 138, LICOS, December 2003.

Richard Disney, Jonathan Haskel, and Ylva Heden. Entry, Exit and Establishment Survival in UK Manufacturing. Journal of Industrial Economics, LI(1):91-112, March 2003a.

Richard Disney, Jonathan Haskel, and Ylva Heden. Restructuring and Productivity Growth in UK Manufacturing. Economic Journal, 113:666-694, July 2003 b.

Álvaro Escribano and J. Luis Guasch. Assessing the Impact of the Investment Climate on Productivity Using Firm-Level Data: Methodology and the Cases of Guatemala, Honduras and Nicaragua. Mimeo, November 2004.

Marcela Eslava, John C. Haltiwanger, Adriana Kugler, and Maurice Kugler. The Effects of Structural Reforms on Productivity and Profitability Enhancing Reallocation: Evidence from Colombia. Journal of Development Economics, 75(2):333-371, December 2004. Special Issue.

Lucia Foster, John C. Haltiwanger, and C. J. Krizan. Aggregate Productivity Growth: Lessons from Microeconomic Evidence. In Edward Dean, Michael Harper, and Charles Hulten, editors, New Developments in Productivity Analysis. University of Chicago Press, 2001.

Lucia Foster, John C. Haltiwanger, and Chad Syverson. Reallocation, Firm Turnover, and Efficiency: Selection on Productivity or Profitability? Mimeo, University of Chicago, July 2003.

Igor Gabrijelčič. Obdavčitev dela, kapitala in potrošnje v Sloveniji (Taxation of Labor, Capital and Consumption in Slovenia). M.A. Thesis, University of Ljubljana, Faculty of Economics, April 2005. In Slovenian language. 
Maja Grgič. Tekstilne domine (Textile Dominos). Delo, July 18, 2005. In Slovenian language.

Zvi Griliches and Haim Regev. Firm Productivity in Israeli Industry 1979-1988. Econometrica, 65:175-203, 1995.

John C. Haltiwanger and Helena Schweiger. Firm Performance and the Business Climate: Where does ICA Fit In? Mimeo, June 2004.

John C. Haltiwanger and Helena Schweiger. Allocative Efficiency and the Business Climate. Mimeo, January 2005.

Boyan Jovanovic. Selection and the Evolution of Industry. Econometrica, 50(3):649-670, 1982.

Janos Kornai, Eric Maskin, and Gerard Roland. Understanding the Soft Budget Constraint. Journal of Economic Literature, 41(4):1095-1136, 2003.

London Economics. Ex-post Evaluation of the Impact of Rescue and Restructuring Aid on the International Competitiveness of the Sector(s) Affected by Such Aid. Final Report to The European Commission - Enterprise Directorate-General. Report, June 2004.

Boris Majcen and Bartlomiej Kaminski. Trade Policy in the Transition Process. In Mojmir Mrak, Matija Rojec, and Carlos Silva-Jáuregui, editors, Slovenia: From Yugoslavia to the European Union, pages 132-149. World Bank, Washington, D.C., 2004.

Domenico J. Marchetti and Francesco Nucci. Labor Effort Over the Business Cycle. Research Paper 424, Banca d'Italia, 2001.

G. Steven Olley and Ariel Pakes. The Dynamics of Productivity in the Telecommunications Equipment Industry. Econometrica, 64(6):1263-1297, 1996.

Robert M. Solow. Technical Change and the Aggregate Production Function. Review of Economics and Statistics, 39:312-320, August 1957.

Tanja Stanković. Polovica študentov opravlja zahtevna dela (Half of Student Workers Work in Jobs Requiring Skilled Workers). Delo, October 12, 2004. In Slovenian language.

James R. Tybout. Manufacturing Firms in Developing Countries: How Well Do They Do, and Why. Journal of Economic Literature, 38:11-44, March 2000.

Johannes Van Biesebroeck. Robustness of Productivity Estimates. Working Paper 10303, NBER, 2004. 
Milan Vodopivec. Labor Market Developments in the 1990s. In Mojmir Mrak, Matija Rojec, and Carlos Silva-Jáuregui, editors, Slovenia: From Yugoslavia to the European Union, pages 292-314. World Bank, Washington, D.C., 2004.

Table A.1: State Aid in the Members of the European Union and Accession Candidates Excluding Agriculture, Fisheries and Transport, 2000-2002

\begin{tabular}{|c|c|c|c|c|c|}
\hline & $\%$ of GDP & Rank & Per capita, EUR & Rank & $\%$ Sectoral aid $f$ \\
\hline \multicolumn{6}{|l|}{ Old members } \\
\hline Belgium & 0.37 & 17 & 83 & 12 & 3 \\
\hline Denmark & 0.72 & 7 & 228 & 3 & 0 \\
\hline Germany & 0.56 & 10 & 147 & 6 & 34 \\
\hline Greece & 0.31 & 18 & 60 & 15 & 0 \\
\hline Spain & 0.55 & 11 & 104 & 9 & 33 \\
\hline France & 0.42 & 15 & 108 & 8 & 40 \\
\hline Ireland & 0.45 & 14 & 160 & 5 & 51 \\
\hline Italy & 0.38 & 16 & 89 & 11 & 4 \\
\hline Luxemburg & 0.26 & 19 & 93 & 10 & 8 \\
\hline Netherlans & 0.19 & 23 & 43 & 21 & 2 \\
\hline Austria & 0.21 & 22 & 59 & 16 & 4 \\
\hline Portugal & 0.55 & 11 & 130 & 7 & 61 \\
\hline Finland & 0.17 & 24 & 46 & 20 & 2 \\
\hline Sweden & 0.16 & 26 & 47 & 19 & 16 \\
\hline Great Britain & 0.17 & 24 & 36 & 22 & 30 \\
\hline \multicolumn{6}{|l|}{ New members } \\
\hline Cyprus $†$ & 2.85 & 3 & 405 & 1 & 77 \\
\hline Czech Republic $\dagger$ & 2.80 & 4 & 187 & 4 & 90 \\
\hline Estonia† & 0.11 & 27 & 5 & 27 & 0 \\
\hline Hungary $\dagger$ & 1.04 & 6 & 56 & 17 & 58 \\
\hline Latvia† & 0.26 & 19 & 10 & 25 & 45 \\
\hline Lithuania $†$ & 0.24 & 21 & 10 & 25 & 96 \\
\hline Malta† & 3.86 & 1 & 404 & 2 & 95 \\
\hline Poland $†$ & 1.29 & 5 & 63 & 14 & 76 \\
\hline Slovenia $†$ & 0.69 & 8 & 70 & 13 & 27 \\
\hline Slovakia & 0.47 & 13 & 22 & 23 & 76 \\
\hline Accession candidates & & & $2000-2003$ & & \\
\hline Bulgaria† & 0.60 & 9 & 11 & 24 & 76 \\
\hline Romania & 3.30 & 2 & 50 & 18 & 67 \\
\hline
\end{tabular}

$\dagger 2000-2003$. $\ddagger$ Including rescue and restructuring aid.

Source: State Aid Scoreboard, Spring 2004, and State Aid Scoreboard online. 


\section{B Sample Selection and Measurement of Productivity}

TFP is calculated as a residual using the standard Cobb-Douglas production function with constant returns to scale and using capital, labor, material and services as inputs. The focus of our paper is the impact of state aid on static and dynamic allocative efficiency in manufacturing. State aid data is only available from 1998 onwards, so the period under study is restricted to the period from 1998 to 2003.

\section{B.1 Sample Selection and Measurement of Inputs}

Available measures for inputs and outputs are somewhat problematic, but not much can be done given the information available. Our measure of capital, $K_{i t, j}$, includes buildings, structures, nonresidential construction, roads, machinery, transport and other equipment, but does not include buildings, machines and equipment under operating leases, and it is impossible to estimate the extent of leasing since this information is not collected separately in Slovenia. ${ }^{39}$ The lease payments show up in the cost of services of the lessee, $S$, and the value of the leased buildings, machines and equipment shows up in $K$ of the lessor. Aggregate measure of capital stock at the total economy level is thus not problematic, but any measure at a more disaggregated level will be fraught with this problem, since the leasing supply firms are not necessarily classified under the same industry as the leasing demand firms.

Labor, $L_{i t, j}$, refers to workers employed in accordance with the Law on Labor Relations, regardless of whether they are in permanent or temporary employment. The number of workers is calculated based on the hours worked, i.e., total hours worked by workers as defined above are divided by the number of hours worked per worker in a year (about 2000 hours, depending on the required hours per day (usually 8) and the number of working days in a given year). $L$ does not include the number of hours worked by students, who

\footnotetext{
${ }^{39}$ Balance sheet includes a category called "Capital revaluation adjustment", but this reflects adjustment of financial investment only. Book values that are reported in the balance sheet are adjusted for depreciation and revaluation until 2001 according to the following formula:

Book value $_{t}=$ Revaluation coefficient $*$ $*\left(\right.$ Book value $_{t-1}-$ Depreciation by prescribed rates by groups of fixed assets) .

The revaluation coefficient was roughly equal to the retail price index before 1998 and to the CPI since then.
} 
have a special status in Slovenia, and there are some indications that some firms were using students as a part of their labor force extensively to reduce the cost of labor, since a worker employed in accordance with the Law on Labor Relations costs the firm 1.9-times more than a student worker. ${ }^{40} L$ also does not include workers who work on the basis of a contract for work or a copyright contract. Separate data on these types of employment are not available at the firm or industry level. Cost of labor, used in the calculation of factor elasticities, does not include the cost of labor of such workers; it only includes wages and benefits of workers employed in accordance with the Law on Labor Relations. Instead, the cost of student workers and workers employed on the basis of a work contract or a copyright contract appears under the cost of services, $S$.

As follows from the above, services, $S_{i t, j}$, include a number of items that should ideally be included in capital, labor, and labor cost, such as rents and student labor. Services also include transport costs, the cost of unfinished goods produced by other firms, and costs of maintenance, marketing and insurance. Detailed information on these is not available.

As a result of the accounting standards which account for the above mentioned problems with measuring inputs, there are a number of firms in our sample with zero capital and/or zero workers and/or zero materials and/or zero services, but it is possible that these zeros are not actually zeroes. Instead of excluding such firms from further analysis, we adjust the production function as explained in subsection B.2.

The number of PASEF firms by year is shown in column (1) of Table B.1. We then eliminate firms that are missing variables needed for the calculation of productivity. First, we exclude firms with zero or negative output (Q). Then we exclude firms for which capital $(K)$, labor $(L)$, cost of services $(S)$, cost of materials $(M)$ and cost of labor are all zero. This reduces our sample by about 10 percent.

Within the remaining sample, on average about 15 percent of firms employ no workers, 5 percent report zero capital, and only 0.4 percent report zero cost of services. The final sample used to estimate the impact of aid is reported in the final column of Table B.1. This sample is smaller than the sample in column (2) of Table B.1 because we exclude firms in the $1^{\text {st }}$ and $99^{\text {th }}$ percentile of the productivity distribution.

\footnotetext{
${ }^{40} \mathrm{~A}$ worker receiving 100.000 SIT net pay costs the firm 115.010 SIT if the worker is a student, and 219.191 SIT if the worker is a regularly employed worker. The difference is due to taxes and contributions. In a survey of 134 firms, 26 percent of them said they do not need more workers due to student labor, and this was especially true for firms with less than 10 or more than 100 workers (Stanković [2004]). New Income Tax Code, in effect since January 1, 2005, is attempting to discourage firms from employing students on positions which actually require a full-time regularly employed worker.
} 
Table B.1: Sample Selection

\begin{tabular}{|c|c|c|c|c|c|c|}
\hline \multirow[b]{2}{*}{ Year } & \multicolumn{2}{|c|}{ Number of firms } & \multicolumn{3}{|c|}{ Share of firms with } & \multirow[b]{3}{*}{ Sample } \\
\hline & $(1)$ & $(2)$ & (3) & $(4)$ & (5) & \\
\hline Year & Raw & After & $K=0$ & $L=0$ & $S=0$ & \\
\hline 1998 & 6495 & 5787 & 0.037 & 0.154 & 0.006 & 4791 \\
\hline 1999 & 6402 & 5769 & 0.036 & 0.153 & 0.007 & 4779 \\
\hline 2000 & 6 & & 042 & 143 & 006 & 98 \\
\hline 2001 & 6265 & 5805 & 0.049 & 0.137 & 0.006 & 4860 \\
\hline 2002 & 6359 & 5893 & 0.055 & 0.138 & 0.002 & 5006 \\
\hline 2003 & 6558 & 5967 & 0.059 & 0.141 & 0.002 & 5101 \\
\hline
\end{tabular}

Source: Own calculations based on PASEF data.

\section{B.2 Measurement of Productivity}

For firms with non-zero inputs, TFP is calculated according to the following equation:

$$
\ln T F P_{i t, j}=\ln Q_{i t, j}-\bar{\alpha}_{K, j} \ln K_{i t, j}-\bar{\alpha}_{L, j} \ln L_{i t, j}-\bar{\alpha}_{M, j} \ln M_{i t, j}-\bar{\alpha}_{S, j} \ln S_{i t, j},
$$

where

$i$ - firm, $t$ - time, $j$ - 2-digit industry

$Q_{i t, j} \quad$ Net sales revenue + change in inventories

$K_{i t, j} \quad$ Book value of fixed assets

$L_{i t, j} \quad$ Average number of workers based on the hours worked

$M_{i t, j} \quad$ Cost of supplies and material

$S_{i t, j} \quad$ Cost of services

For firms with zero labor, zero capital, and zero labor and capital, we calculate the production function and hence TFP using the inputs that were available and interpret the inputs as composite inputs. Equation (B.1) is thus modified according to:

$$
\begin{aligned}
& \ln T F P_{i t, r}=\ln Q_{i t, r}-\bar{\alpha}_{K, r} \ln K_{i t, r}-\bar{\alpha}_{M, r} \ln M_{i t, r}-\bar{\alpha}_{S, r} \ln S_{i t, r} \\
& \ln T F P_{i t, r}=\ln Q_{i t, r}-\bar{\alpha}_{L, r} \ln L_{i t, r}-\bar{\alpha}_{M, r} \ln M_{i t, r}-\bar{\alpha}_{S, r} \ln S_{i t, r} \\
& \ln T F P_{i t, r}=\ln Q_{i t, r}-\bar{\alpha}_{M, r} \ln M_{i t, r}-\bar{\alpha}_{S, r} \ln S_{i t, r}
\end{aligned}
$$

where $r$ denotes 1-digit industry ${ }^{41}$ and the rest is the same as in (B.1). Equation (B.2a) refers to zero labor firms, equation (B.2b) to zero capital firms, and equation (B.2c) to zero

\footnotetext{
${ }^{41}$ These were calculated at the 1-digit industry level to minimize measurement error due to outliers, since there were only a few such firms in some 2-digit industries.
} 
capital and labor firms.

Measures of factor elasticities, $\bar{\alpha}_{K, j}, \bar{\alpha}_{L, j}, \bar{\alpha}_{M, j}$, and $\bar{\alpha}_{S, j}$, were estimated at the 2-digit industry level (and $\bar{\alpha}_{K, r}, \bar{\alpha}_{L, r}, \bar{\alpha}_{M, r}$, and $\bar{\alpha}_{S, r}$ at the 1-digit industry level) using factor cost shares with imputed user cost of capital $^{42}$ and under the assumption of constant returns to scale. Factor shares are averaged across the years 1996-2003, using the number of firms in 2-digit industry $j$ (1-digit industry $r$ ) as weights to minimize the measurement errors. ${ }^{43}$

We experimented with OLS estimation of the production function as an alternative way of computing factor elasticities and TFP. We found that the rank ordering and the quantitative variation in firm-level TFP were not very sensitive to the estimation methodology used to calculate TFP, despite the variation in the factor elasticities - the correlation coefficients between the various pairs of measures were 0.80 or higher. This finding is similar in spirit to the finding of Van Biesebroeck [2004] who finds that the distributional properties of firm-level TFP are reasonably robust to a wide variety of estimation methods.

LP is calculated in a standard way as $\ln L P_{i t}=\ln \frac{Q_{i t}}{L_{i t}}$. As before, we exclude firms with LP below the $1^{\text {st }}$ and above the $99^{\text {th }}$ percentile from further analysis.

Using the described methodology and following Baily et al. [1992], the level of productivity in industry $j$ in year $t$ is calculated as follows:

$$
P_{t, j}=\sum_{i \in j} s_{i t, j} p_{i t, j}
$$

where $s_{i t, j}$ is the share of the $i$-th firm's output in industry $j$ 's output in year $t$ in current prices $\left(\frac{Q_{i t, j}}{Q_{t, j}}\right)$ and $p_{i t, j}$ is either $\log$ of TFP or $\log$ LP of firm $i$ in industry $j$ at time $t$.

\section{B.3 User Cost of Capital}

User cost of capital is calculated at the level of 2-digit industry according to the following formula (slightly adjusted formula from Marchetti and Nucci [2001]):

\footnotetext{
${ }^{42}$ Refer to Appendix B.3 for details on the calculation of the user cost of capital.

${ }^{43}$ This approach is based on the strong assumptions that factors are paid their marginal products.
} 


$$
\begin{aligned}
& u c K_{t, j}=\frac{P_{t}^{I}}{P_{t}^{P}} \frac{1-e t r_{t}}{1-\operatorname{taxr}_{t}}\left\{\left(\text { sstdebt }_{t, j} * r_{t}^{s t l}+\text { sltdebt } * r_{t}^{l t l}\right) *\left(1-\operatorname{taxr}_{t}\right)\right. \\
& \left.+s e q_{t, j} * r_{t}^{e}+\left[s s t r_{t, j} * \delta^{s t r}+\left(1-s s t r_{t, j}\right) \delta^{m a c h}\right]-\frac{P_{t}^{I}-P_{t-1}^{I}}{P_{t-1}^{I}}\right\},
\end{aligned}
$$

where $t$ denotes time, $j$ denotes 2 - digit industry, $u c K$ is user cost of capital, $P^{I}$ is capital goods price index, $P^{P}$ is producer price index, etr is effective corporate tax rate, taxr is corporate tax rate $(25 \%)$, sstdebt is share of short-term debt in liabilities and equity, $r^{\text {stl }}$ is real interest rate on short-term debt, sltdebt is share of long-term debt in liabilities and equity, $r^{l t l}$ is real interest rate on long-term debt, seq is share of equity in liabilities and equity, $r^{e}$ is real rate of return on government bonds, sstr is share of buildings, plants and property in tangible assets, $\delta^{s t r}$ is rate of depreciation of buildings, plants and property $(2.5 \%), \delta^{\text {mach }}$ is rate of depreciation of machinery and equipment (15\%). Shares of short term debt, long term debt and equity in liabilities are calculated at the level of 2-digit industry, excluding firms with negative equity (not a measurement error or a mistake, just a consequence of relatively low equity requirements for the registration of a firm).

Interest rate on short term debt $\left(r^{s t l}\right)$ is taken to be equal to the average commercial banks' nominal interest rate on short term working capital loans to firms (tolar indexation clause). Interest rate on long term debt $\left(r^{l t l}\right)$ is taken to be equal to the average commercial banks' nominal interest rate on long term loans for capital assets (tolar indexation clause). Source for both of these is the Monthly Bulletin of the Bank of Slovenia, and they are available at the annual level. Interest rate on equity $\left(r^{e}\right)$ is usually set equal to the riskfree rate - normally interest rate on 10-year government bonds. However, these data are available only from 2002 onwards for Slovenia, as there were no comparable bonds issued before that (some were issued with a euro clause). Prior to 2002, we set the interest rate on equity to be equal to the interest rate on 181 days - 1 year time deposits (since the interest rates on these and on the 10-year government bonds were almost identical in 2002 and 2003).

Effective tax rates are taken from Table 24 on page 66 in Gabrijelčič [2005]. 


\section{Definition of Small, Medium, and Large Firms Ac- cording to Article 51 of the Law on Enterprises}

In the period 1993-2001, the following criteria were used to define the size of firms in the preparation of the annual accounting reports (Article 51 of the Law on Enterprises):

- Average number of persons in paid employment,

- Total annual revenues, and

- Average value of assets at the beginning and the end of the business year.

In 2002, these criteria were slightly modified (now Article 52 of the Law on Enterprises) and are the following:

- Average number of persons in paid employment,

- Net sales revenue (rather than total revenue as before) in the previous business year, and

- Value of assets at the end of the business year.

The numbers and amounts used are represented in Table C.1. In every case, the firm has to satisfy at least two of the above criteria to be put in a certain size class. We applied these criteria to our data to check if the existing variable in the database is indeed in accordance with the Law on Enterprises criteria, and found that there are a number of discrepancies. Most strikingly, there are more small and large firms, and fewer medium firms, than the existing variable in the database would suggest.

Since this was the case, we contacted AJPES to find out what the procedure for assigning a value of this variable to firms was. Prior to 2002, firms classified themselves as small, medium, or large firms, and APP (Agency for Payments, predecessor of AJPES) checked their classification "manually" by checking the firms' classification and then checking the value of the underlying criteria. APP never changed the classification of the firms by itself - it only did so after contacting the firms and discussing the issue with them. This was supposedly the procedure, but it is unclear or unknown whether all APP subsidiaries strictly followed it and if they checked the firms' self-classifications in the first place. It is thus likely that there are misclassifications in the existing variable due to a "human error".

We were told that firms would often classify themselves as small even if they were actually medium firms because small firms were not obliged to have their annual reports audited, and medium and large firms were obliged to do so. Hence, it it unclear to us why the number of small firms actually increases. From 2002 onwards, AJPES uses a software to 
Table C.1: Criteria for Classifying Firms as Small, Medium and Large According to the Law on Enterprises

\begin{tabular}{|c|c|c|c|c|}
\hline Criteria & Period & Small & Medium & Large \\
\hline $\begin{array}{l}\text { Average number } \\
\text { of persons in } \\
\text { paid employment }\end{array}$ & $\begin{array}{c}1993-1996 \\
\& \\
1997-2001\end{array}$ & At most 50 & At most 250 & \multirow{3}{*}{$\begin{array}{l}\text { - Exceeds at least } \\
\text { two of the criteria } \\
\text { for medium firms } \\
\text { - Banks, insurance } \\
\text { companies, and } \\
\text { firms that must }\end{array}$} \\
\hline \multirow[t]{2}{*}{ Annual revenue } & 1993-1996 & $\begin{array}{l}\text { less than } \\
200.000 .000 \mathrm{SIT}\end{array}$ & $\begin{array}{l}\text { less than } \\
800.000 .000 \text { SIT }\end{array}$ & \\
\hline & $1997-2001$ & $\begin{array}{l}\text { less than } \\
280.000 .000 \text { SIT }\end{array}$ & $\begin{array}{l}\text { less than } \\
1.100 .000 .000 \text { SIT }\end{array}$ & \\
\hline \multirow[t]{2}{*}{$\begin{array}{l}\text { Average value of } \\
\text { assets }\end{array}$} & 1993-1996 & $\begin{array}{l}\text { at most } \\
100.000 .000 \mathrm{SIT}\end{array}$ & $\begin{array}{l}\text { at most } \\
400.000 .000 \mathrm{SIT}\end{array}$ & \multirow{2}{*}{$\begin{array}{l}\text { consolidated } \\
\text { annual } \\
\text { accounting } \\
\text { reports }\end{array}$} \\
\hline & $1997-2001$ & $\begin{array}{l}\text { at most } \\
140.000 .000 \text { SIT }\end{array}$ & $\begin{array}{l}\text { at most } \\
550.000 .000 \mathrm{SIT}\end{array}$ & \\
\hline $\begin{array}{l}\text { Average number } \\
\text { of persons in } \\
\text { paid employment }\end{array}$ & \multirow{3}{*}{$\begin{array}{c}\text { from } 2002 \\
\text { onwards }\end{array}$} & At most 50 & At most 250 & \multirow{3}{*}{$\begin{array}{l}\text { - Neither a small } \\
\text { nor a medium } \\
\text { firm } \\
\text { - Banks, insurance } \\
\text { companies, and } \\
\text { firms that must } \\
\text { prepare } \\
\text { consolidated } \\
\text { annual } \\
\text { accounting } \\
\text { reports }\end{array}$} \\
\hline Net sales revenue & & $\begin{array}{l}\text { less than } \\
1.000 .000 .000 \mathrm{SIT}\end{array}$ & $\begin{array}{l}\text { less than } \\
4.000 .000 .000 \mathrm{SIT}\end{array}$ & \\
\hline $\begin{array}{l}\text { Value of assets at } \\
\text { the end of the } \\
\text { business year }\end{array}$ & & $\begin{array}{l}\text { at most } \\
500.000 .000 \text { SIT }\end{array}$ & $\begin{array}{l}\text { at most } \\
2.000 .000 .000 \mathrm{SIT}\end{array}$ & \\
\hline
\end{tabular}

Source: Official Gazette of the Republic of Slovenia On-line.

check for possible misclassifications, so there should be no more misclassifications assignable to human errors. 
Table D.1: List of NACE Rev. 3 Codes and Their Names used in this Paper

\begin{tabular}{cl}
\hline \hline NACE & Name \\
\hline $\mathbf{1 5}$ & Manufacture of Food, Beverages, and Animal Feeds \\
$\mathbf{1 7}$ & Manufacture of Textiles \\
$\mathbf{1 9}$ & Manufacture of Clothes; Tanning and Treatment of Fur \\
$\mathbf{2 0}$ & Manufacture of Leather and Leather Products \\
$\mathbf{2 1}$ & Manufacture of Wood and Wood Products \\
$\mathbf{2 2}$ & Publishing and Printing \\
$\mathbf{2 3}$ & Manufacture of Coke, Petroleum Products and Nuclear Fuel \\
$\mathbf{2 4}$ & Manufacture of Chemicals, Chemical Products, and Man-Made Fibers \\
$\mathbf{2 5}$ & Manufacture of Rubber and Plastic Products \\
$\mathbf{2 6}$ & Manufacture of Other Non-Metal Mineral Products \\
$\mathbf{2 7}$ & Manufacture of Metals \\
$\mathbf{2 8}$ & Manufacture of Metal Products, Except Machinery and Equipment \\
$\mathbf{2 9}$ & Manufacture of Machinery and Equipment \\
$\mathbf{3 0}$ & Manufacture of Office Machinery and Computers \\
$\mathbf{3 1}$ & Manufacture of Electrical Machinery \\
$\mathbf{3 2}$ & Manufacture of TV and Radio Sets, and Equipment \\
$\mathbf{3 3}$ & Manufacture of Medical, Precision, and Optical Instruments \\
$\mathbf{3 4}$ & Manufacture of Motor Vehicles and Trailers \\
$\mathbf{3 5}$ & Manufacture of Other Transport Equipment \\
$\mathbf{3 6}$ & Manufacture of Furniture; Manufacturing n.e.c. \\
$\mathbf{3 7}$ & Recycling \\
\hline
\end{tabular}

